Review Article

\title{
Monoclonal Antibody to CD14, TLR4, or CD11b: Impact of Epitope and Isotype Specificity on ROS Generation by Human Granulocytes and Monocytes
}

\author{
Dmitry S. Kabanov $\mathbb{D}^{1}$, Sergey V. Grachev $\mathbb{D}^{1,2}$ and Isabella R. Prokhorenko $\mathbb{D}^{1}$ \\ ${ }^{1}$ Department of Molecular Biomedicine, Institute of Basic Biological Problems, Federal Research Center "Pushchino Scientific Center \\ for Biological Research of the Russian Academy of Sciences", Pushchino 142290, Russia \\ ${ }^{2}$ Department of Human Pathology of the Institute of Clinical Medicine, Federal State Autonomous Educational Institution of Higher \\ Education I. M. Sechenov's First Moscow State Medical University of Russian Healthcare Ministry (Sechenov University), \\ Moscow 119991, Russia \\ Correspondence should be addressed to Dmitry S. Kabanov; kabanovd1@rambler.ru
}

Received 19 July 2020; Revised 24 September 2020; Accepted 10 November 2020; Published 21 November 2020

Academic Editor: Luciano Saso

Copyright (C) 2020 Dmitry S. Kabanov et al. This is an open access article distributed under the Creative Commons Attribution License, which permits unrestricted use, distribution, and reproduction in any medium, provided the original work is properly cited.

\begin{abstract}
Lipopolysaccharides (LPSs or endotoxins) from Gram-negative bacteria represent pathogen-associated molecular patterns (PAMPs) that are recognized by CD14 and Toll-like receptor 4 (TLR4). Lipopolysaccharides prime polymorphonuclear leukocytes (PMNs) for substantial production of reactive oxygen species (ROS) during its response to secondary stimuli such as chemoattractants or pathogens. The excessive ROS production can damage surrounding host tissues, thereby amplifying the inflammatory reaction caused by pathogens. Today, specific antibodies against CD14, TLR4, and CD11b are being used as the essential tools to elucidate the role of these receptors in acute inflammation and some of these antibodies have advised as therapeutic agents for clinical use. Because each antibody has two antigen-binding arms $\left[\mathrm{F}\left(\mathrm{ab}^{\prime}\right)_{2}\right]$ and one $\mathrm{Fc}$ arm, its effect on cellular response is much more complicated rather than simple blockage of target receptor. In fact, IgG antibody, once bound to target receptor, engages $\mathrm{Fc}$ receptors $\gamma$ (Fc $\gamma \mathrm{Rs}$ ) and thereby is able to activate the adaptive immune system. The consequences of antibody-dependent binary heterotypic association of CD14, TLR4, or CD11b with Fc $\gamma$ Rs as well as homotypic one on ROS production are not well elucidated. Moreover, the consequences of antigenic recognition of CD14, TLR4, or CD11b by specific $\mathrm{F}\left(\mathrm{ab}^{\prime}\right)_{2}$ fragments are not always investigated. In this review, we will discuss known mechanisms underlying the therapeutic efficiency of CD14, TLR4, and CD11b/CD18 antibodies with a focus on LPS-dependent ROS or cytokine production by PMNs or monocytes. The impacts of $\mathrm{F}\left(\mathrm{ab}^{\prime}\right)_{2}$ as well as antibody IgG subclasses (isotypes) in therapeutic efficiency or agonistic potency of known antibodies against abovementioned receptors are presented. We also pay attention to how the efficiency of different IgG antibody subclasses is modulated during LPS-induced inflammation and by production of priming agents such as interferon $\gamma($ IFN- $\gamma)$. Our review reinforces the molecular targets and therapeutic approaches to amelioration of harmful consequences of excessive activation of human pattern recognition receptors.
\end{abstract}

\section{Introduction}

Inflammatory and immune diseases affect millions of people worldwide, providing an impetus to develop new antiinflammatory and immunomodulatory therapies. Over the past two decades, great progress has been made in elucidating the molecular basis of the inflammation process during infec- tious, autoimmune, and malignant diseases [1-4]. It favors the development of new therapeutic drugs directly targeting cell surface or intracellular molecules involved in the initiation and progression of inflammation. In the case of endotoxemia, the major attention has been on application of LPS analogs with "under-acylated" lipid A structures, synthetic nontoxic lipid A derivatives, monoclonal antibodies to lipid 
A or truncated Re-LPS structure, blocking antibodies against both cell surface receptors and cytokines, and to other intracellular small molecule antagonists for therapeutic purposes. Today, a range of specific antibodies against CD14, TLR4, and CD11b are being used as the essential tool to elucidate their role in acute inflammation [1,5-16]. We have shown earlier that some certain antibodies such as anti$\mathrm{CD} 11 \mathrm{~b}^{\mathrm{ICRF}-44} \mathrm{Fc}{ }^{\text {mIgG1 }}$ or anti-TLR $4^{\mathrm{HTA} 125} \mathrm{Fc}{ }^{\mathrm{mIgG} 2 \mathrm{a}}$ are unable to ameliorate significantly the $\mathrm{N}$-formyl-methionylleucyl-phenylalanine- (fMLP-) triggered ROS production (luminol) from LPS-primed PMNs [12, 13], while antiCD $14^{\text {UCHM-1 }}{ }^{\text {Fc }}{ }^{\text {IgG2a }}$ suppresses LPS priming successfully [14]. Molecular mechanisms underlying our observations, however, have not been described. So, in this review, we discuss molecular mechanisms underlying LPS-induced functional responses of human PMNs and monocytes/macrophages such as ROS generation and production of cytokines after cell exposure to mouse IgG (mIgG) antibody to CD14, TLR4, or CD11b.

ROS is a collective term that often includes not only superoxide anion radical $\left(\mathrm{O}_{2}{ }^{-}\right)$but other oxygen radicals such as hydroxyl $\left(\mathrm{OH}^{-}\right)$, peroxyl $\left(\mathrm{RO}_{2}\right)$, alkoxyl ( $\left.\mathrm{RO}\right)$, hydroperoxyl $\left(\mathrm{HO}_{2}{ }^{\circ}\right)$, and also nonradicals as hydrogen peroxide $\left(\mathrm{H}_{2} \mathrm{O}_{2}\right)$, hypochlorous acid $(\mathrm{HOCl})$, singlet oxygen $\left(\Delta \mathrm{gO}_{2}\right)$, and peroxynitrite $\left(\mathrm{ONOO}^{-}\right)$[17]. Among them, $\mathrm{H}_{2} \mathrm{O}_{2}$ is relatively stable diffusible oxidant acting as a signaling molecule and second messenger in the inflammatory settings. Today, it is known that signaling or damaging actions of ROS are determined by its amount, type, and cellular location. For example, $\mathrm{H}_{2} \mathrm{O}_{2}$ has been shown to be involved in activation of nuclear factor NF- $\kappa \mathrm{B}$ and probably in MAPK signaling cascades [18-22].

Circulating leukocytes are programmed for distinct functions in human physiology. The three main antimicrobial functions are accepted for PMNs: phagocytosis, degranulation, and the release of nuclear material in the form of PMN extracellular traps. Nowadays, it is recognized that PMNs can produce cytokines, modulate activities of neighboring cells, contribute to the resolution of inflammation, regulate macrophages for long-term immune responses, and even have a role in innate memory $[23,24]$. The main function of monocytes is the "processing" and degradation of antigens. Once produced from the bone marrow into the blood, circulating monocytes should be rapidly activated by inflammatory signals and migrate to areas of inflammation where they can differentiate into the proinflammatory (M1) or anti-inflammatory (M2) phenotypes known as tissues macrophages. In the M1 state, the activated monocytemacrophages undergo a metabolic switch from the oxidative phosphorylation to glycolysis. Inhibition of oxidative phosphorylation increases ROS production which exerts bactericidal activities. During the resolution of inflammation, abundance of anti-inflammatory (M2) monocytemacrophages with more oxidative phosphorylation phenotype is increased [25]. Classically activated M1 monocytemacrophages have elevated microbicidal function associated with the ability to secrete high amount of proinflammatory cytokines (TNF- $\alpha$, IL- $1 \beta$, and IL-12) and ROS, while alternatively activated M2 monocyte-macrophages produce high levels of anti-inflammatory mediators (IL-10 and TGF- $\beta$ ) [26].

A change in redox homeostasis may facilitate differentiation of monocytes into macrophages [26]. In fact, in human myeloid leukemia PLB-985 cells, during VD3-triggered monocyte-to-macrophage differentiation, the expression and translocation of nicotinamide adenine dinucleotide phosphate (NADPH) oxidase components to the plasma membrane coincides with upregulation of surface markers such as CD11b and CD36 [26, 27]. Mitochondrial ROS (mitoROS) contribute to LPS-induced cytokine release by monocyte-macrophages $[18,28]$. For example, mitoROS regulate IL- $1 \beta$ transcription (inflammasome priming), but may also regulate the maturation and secretion of IL- $1 \beta$ (inflammasome activation) $[18,29]$.

ROS are by-products of numerous enzymatic reactions in various cell compartments, including the cytoplasm, cell membrane, endoplasmic reticulum, mitochondria, and peroxisome [18]. It has been suggested that peripheral blood monocytes depend on oxidative phosphorylation (ATP synthesis) for their energy supply, whereas PMNs do not. PMNs lose their mitochondrial dependency during maturation from bone marrow mitochondrion-rich precursors into peripheral blood PMNs with relative few mitochondria [30]. As the result, it has been proposed that mitochondria in PMNs (unlike monocyte-macrophages) do not play a role in energy metabolism, but maintain mitochondrial membrane potential for apoptotic signaling [25]. PMNs during phagocytosis use large quantities of molecular $\mathrm{O}_{2}$ not for mitochondrial respiration, but, rather, to generate $\mathrm{O}_{2}{ }^{--}$and other oxidants via a respiratory burst catalyzed by NADPH oxidase [31].

NADPH oxidase is the enzyme responsible for $\mathrm{O}_{2}{ }^{--}$production [32]. This multicomponent enzyme system is composed of two transmembrane proteins $\left(\mathrm{p} 22^{\text {phox }}\right.$ and gp91 ${ }^{\text {phox }} /$ NOX2 forming cytochrome $b_{558}$ ), three cytosolic proteins ( $\mathrm{p} 40^{\mathrm{phox}}, \mathrm{p} 47^{\mathrm{phox}}$, and $\left.\mathrm{p} 67^{\mathrm{phox}}\right)$, and GTPase (Rac1 or Rac2). These components of NADPH oxidase are assembled at membrane sites upon transition of PMNs to a state of enhanced responsiveness known as priming. Three major events accompany activation of NADPH oxidase: (1) protein phosphorylation, (2) activation of GTPases, and (3) translocation of cytosolic components of NADPH oxidase to plasma membrane or to membrane of intracellular granules. Actually, NADPH oxidase in PMNs exists in different states: resting, primed, activated, or inactivated [33]. It has been demonstrated that $\mathrm{O}_{2}{ }^{-}$/ROS derived by NADPH oxidase are critically involved in LPS intracellular signaling leading to PMN priming as well as to maintenance of the resting or nonprimed state [34-37]. The primed PMNs have been identified in humans with infections, rheumatoid arthritis, chronic kidney disease, traumatic injury, and acute respiratory distress syndrome [38].

As known, PMNs express a range of receptors including $\beta_{2}$ integrins (CD11/CD18) and $\mathrm{Fc}$ receptors $\gamma(\mathrm{Fc} \gamma \mathrm{Rs})$ which are capable of initiating complex intracellular signaling events robustly activating NADPH oxidase. In addition, some members of $G$ protein-coupled receptors (GPCRs), especially fMLP receptor FPR1, can directly activate NADPH oxidase, although to a lesser extent than what has been 
observed with activated integrins or Fc $\gamma$ Rs [32]. It is necessary to note that LPS itself does not elicit in PMN significant $\mathrm{O}_{2}{ }^{--}$/ ROS production but transforms them into a primed state in which NADPH oxidase is not fully assembled but becomes more susceptible to activation by secondary stimuli [32-34, 39, 40].

\section{TLR4 and Their Intracellular Signaling Molecules}

LPS in the bloodstream is recognized by LPS-binding protein (LBP) that transfers them to CD14 followed by their presentation to MD-2.TLR4 on the surface of monocytes and PMNs $[1,5,6,11,41-43]$. Structural LPS-induced rearrangements in MD-2.TLR4 trigger TLR4 partitioning into lipid rafts where it undergoes homotypic dimerization facilitating signal transduction events. TLR4 operates with the assistance of other cell surface receptors which are assembled in the LPS-induced "receptor cluster" [6]. Besides CD14 and TLR4, other receptors including the $\beta_{2}$ integrin $\mathrm{CD} 11 \mathrm{~b} / \mathrm{CD} 18$ and Fc $\gamma$ Rs (CD16A, CD32, and CD64) have been also detected as constituents of monocyte LPSinduced "receptor cluster" $[41,42,44]$.

MyD88-dependent and MyD88-independent TRIFdependent signaling pathways have been described in monocytes following TLR4 activation $[45,46]$. These signaling pathways are dependent on Toll/interleukin-1 adaptor proteins including MyD88, TIRAP/MAL, TRIF/TICAM-1, and TRAM/TICAM-2 [47-49]. It has been shown that the LPScaused initiation of MyD88-dependent pathway results in rapid NF- $\kappa \mathrm{B}$ activation and release of proinflammatory cytokines (TNF- $\alpha$, IL-1 $\beta$, and IL-6) and chemokines (MCP-1, MIP-3 $\alpha$, and IL-8). Moreover, in monocytes, the LPScaused initiation of the MyD88-independent pathway results in rapid activation of interferon regulatory factor 3 (IRF3) leading to release of beta interferon (IFN- $\beta$ ) and to the second delayed NF- $\kappa \mathrm{B}$ activation $[50,51]$. Unlike monocytes, the MyD88-independent signaling pathway cannot be mobilized in PMNs in the response to LPS [52].

An amplified $\mathrm{O}_{2}{ }^{--} / \mathrm{ROS}$ production from LPS-primed and fMLP-stimulated PMNs is the result at least of two converging intracellular signaling pathways. The first LPS-induced signaling pathway engages in PMNs such adaptor proteins as MyD88, TIRAP/MAL, IRAK, TRAF6, and TAK1. Among them, TAK1 is linked to MAPK signaling cascades [52]. After 20 minutes of PMN exposure to LPS, the MKK3-dependent phosphorylation of p38 MAPK is observed [53]. The p38 MAPK-dependent translocation of cytochrome $b_{558}$ and $\mathrm{p} 47^{\text {phox }}$ but not $\mathrm{p} 67^{\text {phox }}$ or Rac2 to the plasma membrane is also known. fMLP in LPS-primed PMNs causes a rapid and strong translocation of the other cytosolic components of NADPH oxidase to the already mobilized cytochrome $b_{558}$ followed by $\mathrm{O}_{2}{ }^{-}$/ROS production [54].

\section{Heterotrimeric $G_{i \alpha 2}$ Proteins and Their Intracellular Signaling Events}

The second AMLP-initiated pathway is realized by FPR1 coupled with heterotrimeric $\mathrm{G}_{\mathrm{i} \alpha 2}$ proteins. The activated
$\mathrm{G}_{\beta \gamma}$ subunit of $\mathrm{G}_{\mathrm{i} \alpha 2}$ initiates concomitant activation of phospholipase $\mathrm{C}$ (PLC) and PI3K signaling pathways. The activity of p38 MAPK and ERK1/2 kinases is also upregulated during activation of $\mathrm{G}$ proteins [55-57]. Activated PLC hydrolyses phosphatidylinositol 4,5-bis-phosphate $\left[\operatorname{PtdIns}(4,5) \mathrm{P}_{2}\right.$ or $\mathrm{PI}(4,5) \mathrm{P}_{2}$ ] in the plasma membrane leading to production of inositol 1,4,5-triphosphate $\left[\operatorname{Ins}(1,4,5) \mathrm{P}_{3}\right]$ that is followed by $\mathrm{Ca}^{2+}$ release from intracellular stores and generation of diacylglycerol (DAG), which in turn activates protein kinase $C(P K C)$. The increase in intracellular free $\mathrm{Ca}^{2+}$ leads to $\mathrm{Ca}^{2+}$ influx into the cell. A rise in $\mathrm{Ca}^{2+}$ is an essential step in PMN activation and $\mathrm{O}_{2}{ }^{-}$/ $\mathrm{ROS}$ generation. Activated PKC induces phosphorylation of several substrates including $\mathrm{p} 47^{\mathrm{phox}}$ of NADPH oxidase. At the same time, activated PI3K produces phosphatidylinositol 3,4,5-triphosphate $\left[\mathrm{PtdIns}(3,4,5) \mathrm{P}_{3}\right.$ or $\left.\mathrm{PI}(3,4,5) \mathrm{P}_{3}\right]$ from $\operatorname{PtdIns}(4,5) \mathrm{P}_{2}$. The ability of wortmannin to inhibit PI3K and to abolish the $\mathrm{fMLP}$-triggered respiratory burst without any effect on agonist-induced $\left[\mathrm{Ca}^{2+}\right]_{i}$ flux or PKC-mediated NADPH oxidase activation has provided strong evidence to support a second-messenger role for $\operatorname{PtdIns}(3,4,5) \mathrm{P}_{3}$ in $\mathrm{O}_{2}{ }^{-}$generation [58].

In monocytes, LPS-induced release of proinflammatory cytokines is mediated by PI3K in both a ROS- and G protein-dependent manner, propagated through NADPH oxidase complex 4 (NOX4). Upregulation of PKB/Akt is completely inhibited by pretreatment of human PBMC with either pertussis toxin (inhibitor of $\mathrm{G}_{\alpha \mathrm{i}}$ PCRs) or apocynin (inhibitor of NADPH oxidase 4) [21].

\section{Human Fc $\gamma$ Receptors and Their Ligands}

Monoclonal antibodies to cell surface receptors such as CD14, TLR4, or CD11b/CD18 have various modes of actions. The simplest mode of their action is mere binding of the antibody to its antigen, thereby interfering or not with receptor activation. On the other hand, the antibody is able to block receptor interaction with their ligand, interfering with a multimerization process or triggering internalization of the receptor. In addition, once bound to antigen, IgG antibodies can engage the adaptive immune system via the interaction of their constant Fc region with $F c \gamma$ Rs [59]. The human $\mathrm{Fc} \gamma \mathrm{R}$ family contains six known members in three subgroups, including CD64, CD32 (CD32A, B, C), and CD16 (CD16A, B) [60]. CD32A is mainly expressed on monocytes $\left(5 \times 10^{4} /\right.$ cell $)$, macrophages, and PMNs $\left(1-4 \times 10^{4} /\right.$ cell), whereas CD32B is on B cells principally [11, 61-63]. The cytoplasmic domain of CD32A contains the immunoreceptor tyrosine-based activation motif (ITAM), while CD32B the immunoreceptor tyrosine-based inhibitory motif (ITIM) [11]. Human CD64 is abundantly expressed on monocytes $\left(15-40 \times 10^{3} /\right.$ cell $)$ while at lower levels on PMNs $\left(1-2 \times 10^{3} /\right.$ cell $)$ and macrophages $\left(1 \times 10^{5} /\right.$ cell $)[61,62]$. Human CD64 could be engaged by human IgG1 or mouse IgG2a (mIgG2a) but not mIgG1 or mIgG2b. Human CD32 appears to be engaged by mIgG1 or mIgG2b preferentially [64-70]. It is becoming increasingly evident that many receptors on myeloid cells do not act in isolation, but rather cooperate with other receptors to 
coordinate responses to stimuli. For example, during immune complex (IC) recognition by the cell, CD11b/CD18 cooperates with CD16B $\left(1-3 \times 10^{5} / \mathrm{PMN}\right)$ to cause $\mathrm{Ca}^{2+}$ flux and ROS generation. CD16 and CD11b/CD18 jointly prime CD32 for ROS generation [71, 72]. In human PMNs, both CD32 and CD16B are able to upregulate PI3K activity. Moreover, simultaneously engaged CD32 and CD16B via "insideout" signaling can recruit and activate $\mathrm{CD} 1 \mathrm{~b} / \mathrm{CD} 18$ on PMNs. Thus, three different types of interaction between Fc $\gamma$ Rs and integrins could be realized: (1) a physical interaction on the cell surface, (2) integrin response that occurs because of Fc $\gamma$ Rs engagement and "inside-out" signalization, and (3) cellular responses to $\mathrm{Fc} \gamma \mathrm{Rs}$ that occur only after integrin occupation or when both receptors are stimulated simultaneously, i.e., "outside-in" signalization [73].

$\mathrm{CD} 11 \mathrm{~b}$ is able to regulate $\operatorname{PtdIns}(4,5) \mathrm{P}_{2}$ generation at the cell membrane through an ADP-ribosylation factor (ARF6)-PIP5K pathway. The increase in $\operatorname{PtdIns}(4,5) \mathrm{P}_{2}$ levels causes association of adaptor protein TIRAP/MAL with the plasma membrane, where it is needed to recruit MyD88 to TLR4 [74]. The functional coupling of aggregated CD64 to the PLD- and PKC-dependent activation of NADPH oxidase in IFN- $\gamma$-primed and IC-stimulated human monocytic U937 cells has been shown earlier. On the other hand, CD32A is coupled to PLC but is independent of PLD activation [75].

\section{CD14-Associated Intracellular Signaling Events}

CD14 is the most excessively studied TLR4 gatekeeper. Because CD14 is a glycosylphosphatidylinositol- (GPI-) anchored membrane protein without a transmembrane sequence, it is believed that CD14 has no intrinsic signaling ability during LPS recognition by innate immune cells. However, the LBP.LPS complex initially binds to CD14 and only then LPS is presented to the MD-2.TLR4 complex. CD14 controls the generation of $\operatorname{PtdIns}(4,5) \mathrm{P}_{2}$ that is required for maximal LPS-induced TLR4-dependent proinflammatory signaling [76]. Moreover, CD14 is essential for LPSdependent activation of phospholipases and MAPKs [77]. All together, these facts indicate CD14 as a promising therapeutic target. The impact of CD14 in TLR4-initiated signaling events has been studied in several works [64, 78-82] including our own [14].

5.1. $\mathrm{CD} 14$ in $\mathrm{Ca}^{2+}$ Signaling. Targeting CD14 by whole anti$\mathrm{CD} 14^{\mathrm{Mo2}} \mathrm{Fc}^{\mathrm{mIgM}}$ antibody is not able to stimulate $\mathrm{Ca}^{2+}$ mobilization in human PMNs (CD14 $2-4 \times 10^{3} /$ cell) $[83,84]$. However, in human monocytes, targeting CD14 $\left(10-135 \times 10^{3} /\right.$ cell $)$ by whole anti-CD14 ${ }^{\mathrm{UCHM}-1} \mathrm{Fc}^{\text {mIgG2a }}$ antibody (divalent-Fc format) causes a rapid $\mathrm{Ca}^{2+}$ mobilization $[64,84]$. This rise in intracellular free $\mathrm{Ca}^{2+}$ is less marked than that seen in the response to anti-CD $322^{\mathrm{CIKM}} \mathrm{Fc}^{\mathrm{mIgG} 1}$ antibody $[64,78]$. Similar to anti-CD14 ${ }^{\mathrm{Mo} 2} \mathrm{Fc} \mathrm{mIgM}^{\mathrm{mIg}}$ antibody, the antigenic recognition of $\mathrm{CD} 14$ by anti-CD14 ${ }^{\mathrm{UCHM}-1}$ $\mathrm{F}\left(\mathrm{ab}^{\prime}\right)_{2}$ fragments (divalent $\mathrm{Fab}_{2}$ format) does not elicit in human monocytes a raise in intracellular free $\mathrm{Ca}^{2+}[78]$.
Thus, in monocytes, $\mathrm{Ca}^{2+}$ signaling could be induced by antibody-dependent association of CD14 with the high affinity receptor CD64. In addition, antibody-dependent homotypic $\mathrm{CD} 32$ association $\left(\mathrm{CD} 32 \leftarrow\right.$ anti-CD32 $\left.{ }^{\mathrm{CIKM} 5} \mathrm{Fc}^{\mathrm{mIgG1}} \rightarrow \mathrm{CD} 32\right)$ is also able to induce $\mathrm{Ca}^{2+}$ mobilization. However, association of two CD32 is less effective for $\mathrm{Ca}^{2+}$ mobilization when compared to heterotypic CD14 association with CD64. When CD64 is saturated, the lower affinity CD32A may also be engaged by mIgG2a antibody (CD14 $\leftarrow$ anti-CD14 ${ }^{\mathrm{UCHM}-}$ $\left.{ }^{1} \mathrm{Fc}^{\mathrm{mIgG} 2 \mathrm{a}} \rightarrow \mathrm{CD} 64 / \mathrm{CD} 32\right)$. It is necessary to note that anti$\mathrm{CD} 14{ }^{\mathrm{UCHM}-1} \mathrm{Fc}^{\mathrm{mIgG2a}}$-induced $\mathrm{Ca}^{2+}$ mobilization is weaker than that caused by fMLP [64]. Thus, G protein-coupled FPR1 appeared to be a more potent inductor of $\mathrm{Ca}^{2+}$ signaling than the engagement of CD32 or CD64 (note not clustering).

Unexpectedly, $\mathrm{Ca}^{2+}$ mobilization in monocytes exposed to anti-CD14 ${ }^{\mathrm{UCHM}-1} \mathrm{Fc}^{\mathrm{mIgG} 2 \mathrm{a}}$ antibody has been not associated with $\mathrm{O}_{2}^{--}$generation (SOD-inhibitable ferricytochrome $\mathrm{C}$ reduction) [64]. Although in our settings the anti$\mathrm{CD} 14^{\mathrm{UCHM}-1} \mathrm{Fc}^{\mathrm{mIgG} 2 \mathrm{a}}$ antibody caused certain priming effect on fMLP-triggered $\mathrm{O}_{2}^{-} /$ROS production by human PMNs, we did not observe any statistically significant differences [14]. The data from other works have suggested that anti$\mathrm{CD} 14^{\mathrm{UCHM}-1} \mathrm{Fc}^{\mathrm{mIgG} 2 \mathrm{a}}$ antibody is able to elicit in monocytes or PMN sufficient signal for phosphoinositide breakdown and $\mathrm{Ca}^{2+}$ mobilization but it is not enough to initiate the assembly of NADPH oxidase and $\mathrm{O}_{2}^{-}$/ROS generation $[14,78]$. Sufficient mobilization of $\mathrm{Ca}^{2+}$ in all monocytes but only in subset of PMN (40\%) has been detected only after $\mathrm{CD} 14$ crosslinking by anti-CD14 ${ }^{\mathrm{Mo} 2} \mathrm{Fc}{ }^{\mathrm{mIgM}}$ or anti$\mathrm{CD} 14^{\mathrm{MEM}-18 / 63 \mathrm{D} 3} \mathrm{Fc}^{\mathrm{mIgG1}}$ antibodies followed by secondary $\mathrm{F}\left(\mathrm{ab}^{\prime}\right)_{2}$ fragments. The broad homotypic aggregation (crosslinking) of CD14 in the plane of plasma membrane has been suggested to be responsible for the robust increase in $\mathrm{H}_{2} \mathrm{O}_{2}$ /ROS production in monocytes while less pronounced in PMNs [80, 81]. The higher sensitivity of monocytes to antibody-dependent initiation of $\mathrm{Ca}^{2+}$ signaling in comparison to PMNs can be explained by the differences in CD14 levels on their cell surfaces [84].

The $\mathrm{Ca}^{2+}$ mobilization induced by CD14 crosslinking is suppressed when PLC or protein tyrosine kinases (PTK) have been inhibited [80]. Thus, only broad CD14 aggregation is able to stimulate substantial rise in intracellular free $\mathrm{Ca}^{2+}$ and $\mathrm{O}_{2}^{-}{ }^{-} /$ROS production. CD14 in monocytes is physically associated with nonreceptor PTK ${ }^{\mathrm{Src}} \mathrm{Lyn}^{\mathrm{p} 53 / 56}$. The crosslinking of CD14 leads to ${ }^{\mathrm{Src}} \mathrm{Lyn}^{\mathrm{p} 53 / 56}$ activation followed by concomitant upregulation of ${ }^{\mathrm{Src}} \mathrm{Frg}^{\mathrm{p} 58}$ and ${ }^{\mathrm{Src}} \mathrm{Hck}^{\mathrm{p} 59 / 61}$ kinases $[85,86]$. Earlier studies have shown that the signaling events triggered by CD14 crosslinking were abolished when the GPI anchor had been replaced by transmembrane sequence, suggesting that the localization to lipid rafts endowed CD14 with signaling ability $[79,80]$. As GPI-anchored receptors have high lateral mobility in the plane of cell membrane, they may be more easily aggregated upon interaction with a specific ligand [81]. Thus, CD14 would function to concentrate LPS at the cell surface for their recognition by other LPSbinding proteins and to facilitation of $\operatorname{PtdIns}(4,5) \mathrm{P}_{2}$ generation [87]. 


\section{Epitope Specificity and Effectiveness of Anti- CD14 Antibodies against LPS-Induced Effects}

LPS-binding sites on CD14 have been intensively studied, and four regions within the $\mathrm{NH}_{2}$-terminal 65 amino acid residues are identified. All of these regions (R) are clustered around the hydrophobic pocket of CD14. R1 $\left(\mathrm{D}_{9} \mathrm{DED}_{12}\right)$ is located close to the wall, whereas $\mathrm{R} 3\left(\mathrm{~A}_{35} \mathrm{VEVE}_{39}\right)$ is at the bottom of the pocket, while $\mathrm{R} 2\left(\mathrm{P}_{22} \mathrm{QPD}_{25}\right)$ and $\mathrm{R} 4$ $\left(\mathrm{D}_{57} \mathrm{ADPRQY}{ }_{63}\right)$ are located at the rim of the pocket. Another three regions of CD14, namely, T1 ( $\left.\mathrm{E}_{7} \mathrm{LDDEDF}_{13}\right)$, T2 $\left(\mathrm{L}_{91}\right.$ RVLAYSRLKE $\left._{101}\right)$, and T3 $\left(\mathrm{P}_{185} \mathrm{GL}\right)$, have been proposed to be involved in LPS transfer to MD-2.TLR4 and therefore are responsible for LPS signaling. R1 within CD14 overlaps with $\mathrm{T} 1$ region. Therefore, the $\mathrm{T} 1 / \mathrm{R} 1$ sequence appears to play a role in both LPS binding and transfer (LPS signaling) to MD-2-TLR4 [88, 89]. The effectiveness of various anti-CD14 antibodies against LPS-induced effects is listed in Table 1.

6.1. Targeting R1 and T1 by 3C10 Antibodies Interferes with LBP.LPS Binding to CD14. Anti-CD $14^{3 \mathrm{C} 10} \mathrm{Fc}^{\mathrm{mIgG} 2 \mathrm{~b}}$ antibody binds to mostly anionic $\mathrm{E}_{7} \mathrm{LDDEDFR}_{14}$ sequence in CD14 that is able to interact with cationic proteins such as serum LBP $[106,111,112]$. Anti-CD14 ${ }^{3 \mathrm{C} 10}$ antibody almost completely prevents PMN priming by LBP.LPS for fMLPtriggered $\mathrm{O}_{2}^{--}$/ROS production (luminol) [90]. So, the first antibody-dependent mechanism downregulating LPS deleterious effects is based on the ability of anti-CD14 antibodies to prevent the binding of LBP.LPS to CD14 and to abolish subsequent LPS transfer to MD-2.TLR4 [106, 111].

6.2. Targeting R4 by MEM-18 Antibodies Suppresses LBP.LPS Binding to CD14. Anti-CD14 ${ }^{\mathrm{MEM}-18} \mathrm{Fc}^{\mathrm{mIgG1}}$ antibody binds to $\mathrm{L}_{51}-\mathrm{A}_{64}$ sequence in $\mathrm{R} 4$ region $\left(\mathrm{D}_{57}-\mathrm{A}_{64}\right)$ of CD14. It is able to interfere with entry of lipid $A$, the hydrophobic region of LPS, into the hydrophobic pocket of CD14 (R4) during CD14 recognition of LBP.LPS, thereby suppressing the harmful effects caused by LPS [113-116]. Thus, despite the differences in isotype, the anti-CD $14^{\mathrm{MEM}-18} \mathrm{Fc}^{\mathrm{mIgG} 1}$ antibody, similar to anti-CD $14{ }^{3 \mathrm{C} 10} \mathrm{Fc}^{\mathrm{mIgG} 2 \mathrm{~b}}$ antibody, prevents the binding of LPS to CD14 [113, 117]. As a result, LPSinduced production of both TNF- $\alpha$ from human monocytes [97, 118] or IL-8 from PBMC [119] has been suppressed. The effectiveness of anti-CD $14^{\mathrm{MEM}-18} \mathrm{Fc}^{\mathrm{mIgG1}}$ antibody can be explained also by its supplementary ability to downregulate CD14 and TLR4, but not CD11b/CD18, from the cell surface as has been shown earlier using differentiated monocytic THP-1 cells $[113,120]$. Since anti-CD $14^{\text {MEM-18 }}$ is a mIgG1 antibody and may be recognized by $\mathrm{Fc} \gamma \mathrm{Rs}$ $\left(\mathrm{CD} 14 \leftarrow\right.$ anti-CD14 $\left.{ }^{\mathrm{MEM}-18} \mathrm{Fc}^{\mathrm{mIgG} 1} \rightarrow \mathrm{CD} 64 / \mathrm{CD} 32\right), \quad$ its mode of action is more complicated $[113,121]$.

It is necessary to note that LPS-induced IL- 8 production has been shown to be suppressed more effectively by antiCD $14^{\text {MEM-18 }}$ antibody than anti-TLR $4^{\mathrm{HTA} 125} \mathrm{Fc}^{\text {mlgG2a }}$ antibody [119]. The effectiveness of anti-CD14 ${ }^{\mathrm{UCHM}-1} \mathrm{Fc}^{\mathrm{mIgG} 2 \mathrm{a}}$ antibody against LPS-induced effects in human monocytes is less evident than that of anti-CD $14^{\mathrm{MEM}-18} \mathrm{Fc}^{\mathrm{mIgG} 1}$ antibody $[97,118]$.
6.3. Targeting R3 by MY4 Antibodies Causes Internalization of CD14 and TLR4. Anti-CD14 ${ }^{\mathrm{MY} 4} \mathrm{Fc}^{\mathrm{mIgG} 2 \mathrm{~b}}$ antibody binds to $\mathrm{S}_{34}-\mathrm{G}_{44}$ sequence of CD14 and does not prime human PMNs for fMLP-triggered $\mathrm{O}_{2}{ }^{-}$/ROS production (reduction of ferricytochrome C) $[104,113]$ but suppresses LBP.LPSinduced CD11b/CD18 mobilization to the cell surface [87]. Moreover, both LPS-induced association of $\mathrm{G}_{\mathrm{i} \alpha 2}$ with PMN plasma membrane and activation of PLD are significantly suppressed by prior cell exposure to anti-CD $14^{\mathrm{MY} 4}$ antibody [104]. The effectiveness of anti-CD $14{ }^{\mathrm{MY} 4} \mathrm{Fc}{ }^{\mathrm{mIgG} 2 \mathrm{~b}}$ antibody against LPS-induced effects is associated with its ability to induce downregulation of CD14 and TLR4 from the cell surface. It is interesting to note that LPS-independent internalization of CD14 and TLR4 during cell response to anti-CD14 ${ }^{\mathrm{MY} 4} \mathrm{Fc}^{\mathrm{mIgG} 2 \mathrm{~b}}$ antibody exceeded that of antiCD $14{ }^{\mathrm{MEM}-18} \mathrm{Fc}{ }^{\mathrm{mIgG1}}$ antibody $[100,104,113]$. Thus, the effectiveness of anti-CD14 ${ }^{\mathrm{MY} 4}$ antibody against LPSinduced effects is based on its ability to block LBP.LPS binding to CD14 and to downregulate CD14 and TLR4 from the cell surface. Why mIgG2b antibodies to CD14 (MY4) or TLR4 (HT4) are internalized better than mIgG1 anti-CD $14^{\mathrm{MEM}-18}$ antibody remain to be elucidated.

6.4. Anti-CD14 Antibodies as a Constituent of Therapeutic Medications. CD14 as evidenced from data presented in Table 1 is involved in LPS-dependent PMN priming [103]. The relative weak effectiveness of anti-CD $14^{\text {UCHM-1 }} \mathrm{Fc}^{\text {mIgG2a }}$ antibody as a suppressor of LPS-dependent PMN priming for fMLP-triggered $\mathrm{O}_{2}{ }^{-}$/ROS production may be explained by its epitope specificity that blocks CD14 incompletely [14]. However, the inhibitory effectiveness of antiCD14 ${ }^{\text {UCHM-1 }}$ antibodies may be improved by replacing their mIgG2a isotype with mouse or human IgG1.

The therapeutic relevance of anti-CD $14^{28 \mathrm{C}} \mathrm{Fc}^{\mathrm{mIgG} 1}$ or anti-CD $14{ }^{18 \mathrm{E} 12} \mathrm{Fc}{ }^{\mathrm{mIgG} 1}$ antibodies against LPS-induced effects has been already studied in vivo in INF- $\gamma$-sensitized Macaca fascicularis [109] and in normal human subjects (anti-CD $\left.14^{\mathrm{IC} 14} \mathrm{Fc}{ }^{\mathrm{mhIgG1}}\right)$ [122]. Anti-CD $14^{28 \mathrm{C} / 18 \mathrm{E} 12} \mathrm{Fc}{ }^{\mathrm{mIgG} 1}$ antibodies protect primates from most of the physiologic and proinflammatory consequences of acute endotoxemia. The intravenous treatment of $M$. fascicularis by antiCD $14^{18 \mathrm{E} 12}$ antibody blocks signaling events without affecting the binding of LPS to CD14 as it has been estimated during LPS-induced production of TNF- $\alpha$. On the other hand, productions of IL- 6 and IL- $1 \beta$ have been inhibited better by another anti-CD $14^{28 \mathrm{C}}$ antibody that is able to block LBP.LPS binding to CD14 [109]. A beneficial anti-CD $14{ }^{\mathrm{IC} 14} \mathrm{Fc}{ }^{\mathrm{mhIgG} 1}$ antibody attenuates acute LPS-induced clinical symptoms and strongly inhibits LPS-induced production of proinflammatory cytokines, while it only delayed the release of the anti-inflammatory cytokines such as soluble TNF receptor type I and IL-1 receptor antagonist [122].

\section{Epitope Specificity and Effectiveness of Anti- TLR4 Antibodies against LPS-Induced Effects}

Human TLR4 is linked to a range of diseases, including infectious disease, atherosclerosis, asthma, cardiac disease, liver disease, renal disease, inflammatory bowel disease, obesity, 
TABLE 1: The capability of antibodies against CD14 affects the LPS-induced effects (the references are indicated inside the square brackets).

\begin{tabular}{|c|c|c|c|c|}
\hline Clone (isotype) & Epitope & $\begin{array}{l}\text { Influence on LPS-induced ef } \\
\text { Does }\end{array}$ & Does not & References \\
\hline $\begin{array}{l}3 C 10 \text { (mIgG2b) } \\
\text { Effectiveness decreases } \\
\text { when LPS } \\
\text { concentration } \\
\text { increases }\end{array}$ & $\mathrm{E}_{7}-\mathrm{R}_{14}$ & $\begin{array}{l}\text { (1) Suppress CD14 binding to LBP-Re-LPS } \\
\text { Salmonella minnesota ( } 1 \mathrm{ng} / \mathrm{ml}) \text { as well as PMN } \\
\text { priming for fMLP-triggered } \mathrm{O}_{2}^{--} / \text {ROS } \\
\text { (2) Whole or } \mathrm{F}\left(\mathrm{ab}^{\prime}\right)_{2} \text { suppress } \mathrm{O}_{2}^{--} / \text {ROS production } \\
\text { in monocytes challenged by Re-LPS Escherichia coli } \\
\quad(1 \mathrm{ng} / \mathrm{ml}, 5 \% \text { blood serum }) \\
\text { (3) Prevent CD11b/CD18 mobilization to the cell } \\
\text { surface in PMNs stimulated by Ra/Rb-LPS E. coli } \\
\text { K12 ( } 30 \mathrm{ng} / \mathrm{ml} \text {, without serum) }\end{array}$ & & {$[90-96]$} \\
\hline biG10 (mIgG1) & $\mathrm{D}_{9}-\mathrm{F}_{13}$ & $\begin{array}{l}\text { (1) Suppress TNF- } \alpha \text { production in whole human } \\
\text { blood exposed to LPS Salmonella abortus-equi } \\
(10 \mathrm{ng} / \mathrm{ml})\end{array}$ & & {$[97,98]$} \\
\hline MY4 (mIgG2b) & $\mathrm{S}_{34}-\mathrm{G}_{44}$ & $\begin{array}{c}\text { (1) Suppress CD14 binding to LBP-Re-LPS } \\
\text { (2) Decrease PMN priming by LPS from E. coli } \\
\text { O55:B5 (10 ng/ml, } 1 \% \text { serum) or E. coli O111:B4 } \\
\text { (10 ng/ml, 10\% serum) } \\
\text { (3) Inhibit phosphatidic acid generation in LPS- } \\
\text { primed and fMLP-stimulated PMNs } \\
\text { (4) Suppress LPS-dependent activation of p38 } \\
\text { MAPK in human PMNs } \\
\text { (5) Whole or Fab suppress LPS uptake by human } \\
\text { monocytes }\end{array}$ & $\begin{array}{l}\text { (1) Affect fMLP-triggered } \\
\mathrm{O}_{2}^{-\cdot} / \text { ROS production from } \\
\text { unprimed PMNs }\end{array}$ & {$[77,94,99-104]$} \\
\hline $60 b c a(\mathrm{mIgG} 1)$ & $\mathrm{S}_{34}-\mathrm{V}_{38}$ & $\begin{array}{l}\text { (1) Prevent LBP.Re-LPS S. minnesota binding to } \\
\text { CD14 } \\
\text { (2) Abolish almost completely PMN priming by } \\
\text { LBP-Re-LPS S. minnesota ( } 1 \mathrm{ng} / \mathrm{ml}) \text { for fMLP- } \\
\text { triggered } \mathrm{O}_{2}^{--} / \mathrm{ROS}\end{array}$ & & {$[90,105]$} \\
\hline $63 \mathrm{D} 3$ (mIgG1) & & $\begin{array}{l}\text { (1) Whole or } \mathrm{F}\left(\mathrm{ab}^{\prime}\right)_{2} \text { suppress weakly LPS-induced } \\
\text { ROS production in human monocytes }\end{array}$ & $\begin{array}{l}\text { (1) Prevent LBP-dependent } \\
\text { delivery of Re-LPS } S \text {. } \\
\text { minnesota to CD14 } \\
\text { (2) Suppress LPS-induced } \\
\text { TNF- } \alpha \text { and IL-8 production }\end{array}$ & {$[91,94,95,106-108]$} \\
\hline $28 C 5$ (mIgG1) & & $\begin{array}{l}\text { (1) Suppress LBP-dependent delivery of Re-LPS S. } \\
\text { minnesota to CD } 14 \\
\text { (2) Suppress LPS-dependent activation of p38 } \\
\text { MAPK }\end{array}$ & & {$[94,109]$} \\
\hline biG14 (mIgG2a) & $\mathrm{E}_{39}-\mathrm{G}_{44}$ & (1) Decrease binding of Ra-LPS E. coli to CD14 & & [97] \\
\hline UCHM-1 (mIgG2a) & & $\begin{array}{l}\text { (1) Suppress LPS-induced IL-8 production by } \\
\text { human retinal pigment epithelial cells } \\
\text { (2) Decrease PMN priming by S- or Re-LPS E. coli } \\
\left(100 \mathrm{ng} / \mathrm{ml}, 2 \% \text { serum) for fMLP-triggered } \mathrm{O}_{2}\right. \\
-/ \text { ROS production }\end{array}$ & & {$[14,110]$} \\
\hline
\end{tabular}

diabetes (types I and II), rheumatoid arthritis, Alzheimer's disease, Parkinson's disease, and multiple sclerosis [1, 6, 61, 123]. As a result, targeting TLR4 has attracted increasing attention in the context of anti-inflammatory medications for patients with different TLR4-dependent complications $[6,15,16,62,106,124-129]$. The data presented in Table 2 represent TLR4 as a promising therapeutic target for "antibody"-based therapy.

The extracellular region of TLR4 can be divided into Nterminal $\left(\mathrm{L}_{52}-\mathrm{P}_{202}\right)$, central $\left(\mathrm{L}_{203}-\mathrm{L}_{348}\right)$, and C-terminal
$\left(\mathrm{K}_{349}-\mathrm{F}_{582}\right)$ domains; each of which contains LRRs 1-6, LRRs 7-12, and LRRs 13-22, respectively [1].

7.1. Targeting the N-Terminal Domain of TLR4. Targeting LRR2-LRR7 $\left(\mathrm{D}_{50}-\mathrm{I}_{190}\right)$ repeats in TLR4 by antiTLR $4{ }^{\mathrm{HTA} 125} \mathrm{FC}^{\text {mIgG2a }}$ antibody does not suppress LPSdependent PMN priming for fMLP-triggered $\mathrm{O}_{2}^{--} / \mathrm{ROS}$ production (luminol) [12, 132]. The same result has been obtained by Sanui et al. [133]. These authors did not observe pronounced inhibitory effect of anti-TLR $4^{\mathrm{HTA} 125}$ antibody 
on LPS-induced PMN priming. However, Stadlbauer et al. [129] showed that the anti-TLR $4^{\text {HTA125 }}$ antibody is able to suppress LPS-induced production of ROS (Phagoburst kit) in PMNs.

When LPS-induced production of IL-6 and IL-8 was studied in the human embryonic cell line HEK293, no inhibitory effect of anti-TLR $4{ }^{\mathrm{HTA} 125} \mathrm{Fc}^{\mathrm{mIgG} 2 \mathrm{a}}$ was detected $[6,11]$. However, in human retinal pigment epithelial cells, antiTLR4 ${ }^{\text {HTA125 }}$ antibody was almost equally as effective as anti-CD $14^{\mathrm{UCHM}-1} \mathrm{Fc}^{\mathrm{mIgG} 2 \mathrm{a}}$ antibody in suppression of LPSinduced IL-8 production. It is interesting to note that simultaneous use of anti-TLR $4^{\mathrm{HTA} 125}$ and anti-CD $14^{\mathrm{UCHM}-1}$ antibodies did not further potentiate antibody inhibitory effectiveness, suggesting that blockage of initial LPS binding to CD14 was highly effective and not further increased when TLR4 was also targeted [110].

The weak inhibitory effectiveness of anti-TLR $4^{\text {HTA125 }}$ $\mathrm{Fc}^{\mathrm{mIgG2a}}$ antibody could be explained by the epitope specificity. This antibody recognizes an antigenic epitope within $\mathrm{D}_{50}-\mathrm{I}_{190}$ sequence and binds to TLR4 irrespective of the presence or absence of MD-2 [132]. Thus, it may be suggested that blockage of LRR2-LRR7 (HTA125) is not enough to prevent LPS.MD-2-induced TLR4 dimerization (Table 2).

7.2. Targeting the C-Terminal Domain of TLR4. Anti$\mathrm{TLR} 4{ }^{\mathrm{HT} 4} \mathrm{Fc}^{\mathrm{mIgG} 2 \mathrm{~b}}$ antibody recognizes the nonlinear epitope within the LRR13 repeat of TLR4. This epitope is composed of several amino acid residues $\left(\mathrm{K}_{349}, \mathrm{~K}_{351} \mathrm{~S}_{352}, \mathrm{G}_{364} \mathrm{NA}\right.$, and $\mathrm{S}_{368} \mathrm{E}$ ) closely located to the TLR4 dimerization interface created by LRR15-LRR17 repeats of two LPS.MD-2-TLR4 complexes. Based on experimental data, it has been assumed that anti-TLR4 ${ }^{\mathrm{HT} 4}$ antibody is unable to prevent LPS.MD-2 binding to TLR4 but nevertheless inhibits LPS.MD-2induced TLR4 internalization. The effectiveness of antiTLR $4{ }^{\mathrm{HT} 4} \mathrm{Fc}{ }^{\mathrm{mIgG} 2 \mathrm{~b}}$ antibody in suppression of lipid Ainduced production of TNF- $\alpha$, IL-6, and IL-12p40 from human leukocytes is better than that of the antiTLR $4{ }^{\mathrm{HTA} 125} \mathrm{Fc}^{\mathrm{mIgG} 2 \mathrm{a}}$ antibody $[1,5,6]$. Taking these facts into consideration, it could be concluded that targeting the C-terminal domain of TLR4 may lead to a more pronounced therapeutic effect than targeting the N-terminal domain of TLR4 by HTA $125^{\text {mIgG2a }}$ or HT52 $2^{\text {mIgG1 }}$ antibodies. The effect of anti-TLR4 ${ }^{\mathrm{HT} 52} \mathrm{Fc}^{\mathrm{mIgG} 1}$ (LRR2-LRR7: $\mathrm{D}_{50}-\mathrm{I}_{190}$ sequence) antibody may be potentiated by simultaneous application with anti-TLR4 ${ }^{\mathrm{HT} 4} \mathrm{Fc}^{\mathrm{mIgG} 2 \mathrm{~b}}$ (LRR13) antibody thus causing double blocking of TLR4 (LRR2-LRR7 and LRR13) [1, 5, 6]. Note that anti-TLR $4^{\mathrm{HTA} 125}$ antibody recognizes the same antigenic epitope as did anti-TLR $4^{\mathrm{HT} 52}$ antibody. We assume that double targeting TLR 4 by anti-TLR $4^{\mathrm{HT} 4}$ and anti-TLR $4{ }^{\mathrm{HTA} 125}$ antibodies would improve the inhibitory effectiveness of the latter.

As has been shown experimentally, the inhibitory effectiveness of anti-TLR $4{ }^{\mathrm{HT} 4} \mathrm{Fc}{ }^{\mathrm{mIgG} 2 \mathrm{~b}}$ or anti-TLR $4{ }^{\mathrm{HT} 52} \mathrm{Fc}^{\mathrm{mIgG} 1}$ is not associated with engagement of $F c \gamma$ Rs. In fact, the inhibitory effectiveness of anti-TLR $4^{\mathrm{HT} 4} \mathrm{Fc}{ }^{\mathrm{mIgG} 2 \mathrm{~b}}$ or anti$\mathrm{TLR} 4{ }^{\mathrm{HT} 52} \mathrm{FC}^{\mathrm{mIgG1}}$ against lipid A-induced effects was unaffected by prior cell exposure to blocking anti-CD $32^{\text {AT- }}$ ${ }^{10} \mathrm{Fc}{ }^{\mathrm{mIgG} 1}$ antibody $[1,5,6]$.
7.3. Targeting Both $N$ - and C-Terminal Domains of TLR4. The improved antibody effectiveness seen with doubletargeted TLR4 led to the generation of a new antiTLR $4{ }^{15 \mathrm{C} 1} \mathrm{Fc}^{\mathrm{mIgG1}}$ antibody recognizing both LRR12 $\left(\mathrm{Y}_{328} \mathrm{~N}\right)$ and LRR13 ( $\left.\mathrm{K}_{349} \mathrm{LK}, \mathrm{E}_{369} \mathrm{VD}\right)$ sequences [11]. Anti-TLR4 ${ }^{15 \mathrm{C} 1}$ antibody blocks TLR4 binding to LPS.MD-2 and TLR4 dimerization as well. In addition, anti-TLR $4^{15 \mathrm{C} 1}$ antibody effectively suppresses LPS-induced IL- 6 and IL-8 production analogous to anti-TLR $4{ }^{\mathrm{HT} 4} \mathrm{Fc}^{\mathrm{mIgG} 2 \mathrm{~b}}$ or antiTLR $4{ }^{\mathrm{HT} 52} \mathrm{Fc}^{\mathrm{mIgG1}}$ antibodies but with stronger effect than anti-TLR $4{ }^{\mathrm{HTA} 125} \mathrm{Fc}^{\text {mIgG2a }}$ antibody $[6,11]$. Furthermore, anti-TLR4 ${ }^{15 \mathrm{C} 1}$ antibody prevents LPS-induced TLR4 partitioning into lipid rafts [61]. As earlier has been shown, the effectiveness of anti-TLR $4{ }^{15 \mathrm{C} 1} \mathrm{Fc}^{\mathrm{mIgG1}}$ antibody is dependent on the engagement of Fc $\gamma$ Rs (CD32) $[1,11]$. Targeting CD32 by anti-CD $32^{\text {IV.3/AT- } 10} \mathrm{Fc}^{\text {mIgG2b }}$ antibodies dramatically reduces the effectiveness of anti-TLR $4^{15 \mathrm{C} 1} \mathrm{Fc}{ }^{\mathrm{mIgG} 1}$ antibody when LPS-induced production of IL- 6 was studied. It is necessary to note that LPS-induced IL-6 production had not been significantly affected by isotype-matched control mIgG1. Thus, in addition to engagement of CD32 (TLR4 $\leftarrow$ anti-TLR $\left.4^{15 \mathrm{Cl}} \mathrm{Fc}^{\mathrm{mIgG} 1} \rightarrow \mathrm{CD} 32\right)$ and its signaling pathway(s), the therapeutic effect of anti-TLR $4^{15 \mathrm{C} 1} \mathrm{Fc}{ }^{\text {mIgG1 }}$ antibody is based on its ability to prevent LPS.MD-2 binding to TLR4 thereby abolishing TLR4 dimerization and its movement into lipid rafts $[1,11,134]$.

7.4. Humanized Anti-TLR4 Antibody and Fc $\gamma$ Rs. The differences in the affinity of Fc $\gamma$ Rs for IgG subclasses have been explored in development of new therapeutic antibodies such as $\mathrm{Hu} 15 \mathrm{C} 1$. This antibody is the humanized version of antiTLR $4{ }^{15 \mathrm{C} 1} \mathrm{FC}^{\mathrm{mIgG} 1}$ antibody $[61,135]$. Two substitutions $\left(\mathrm{N}_{325} \rightarrow \mathrm{S}\right.$ and $\left.\mathrm{L}_{328} \rightarrow \mathrm{F}\right)$ have been introduced into $\mathrm{Fc}$ arm of anti-TLR $4^{15 \mathrm{Cl}} \mathrm{Fc}^{\mathrm{mIgG1}}$ antibody to amplify its inhibitory effectiveness. As a result, the affinity of the new anti$\mathrm{TLR}^{\mathrm{Hu}{ }^{\mathrm{HCl}} \mathrm{Fc}} \mathrm{FIgG1}^{\mathrm{hIg}}$ for CD64 is potentiated, while for CD16, it is eliminated. An intermediate affinity of antiTLR $4{ }^{\mathrm{Hu} 15 \mathrm{C} 1} \mathrm{FC}^{\mathrm{hIgG1}}$ for CD32 was detected. Thus, CD64 (TLR4 $\leftarrow$ anti-TLR4 $\left.{ }^{\mathrm{Hu} 15 \mathrm{Cl}} \mathrm{Fc}^{\mathrm{hIgG1}} \rightarrow \mathrm{CD} 64 / \mathrm{CD} 32\right)$ is viewed as the first contributor to the potent inhibitory effectiveness of anti-TLR $4^{\mathrm{Hu} 15 \mathrm{C} 1} \mathrm{Fc} \mathrm{hIgG1}^{\mathrm{h}}$ antibody. In addition, CD32initiated ITAMi signaling is expected when CD64 would be not available. The blockage of CD32B does not change significantly the inhibitory effectiveness of anti-TLR 4 Hu15C1 antibody. When anti-TLR4 $4^{\mathrm{Hu} 15 \mathrm{C} 1}$ antibody had been compared with the parental anti-TLR $4{ }^{15 \mathrm{C} 1} \mathrm{Fc}^{\mathrm{mIgG} 1}$ antibody, the former antibody was more effective than the latter in inhibition of LPS-induced effects. In addition, it has been shown using neuronal originated HEK293 cells that CD32A is involved in the inhibitory potency of antiTLR4 $4^{\mathrm{Hu} 15 \mathrm{C} 1}$ antibody. It was also discovered that the inhibitory potency of anti-TLR $4^{\mathrm{Hu} 15 \mathrm{C} 1}$ antibody against LPS-induced effects is much higher in CD32A-positive HEK293 cells than in CD32A-negative ones. Besides engagement of CD64 and CD32, the anti-TLR4 ${ }^{\mathrm{Hu} 15 \mathrm{C} 1}$ antibody is able to interfere with LPS-induced TLR4 dimerization thereby preventing TLR4 partitioning into lipid rafts. Thus, it is postulated that dimerization of TLR4 is a prerequisite for TLR4 clustering [61]. 


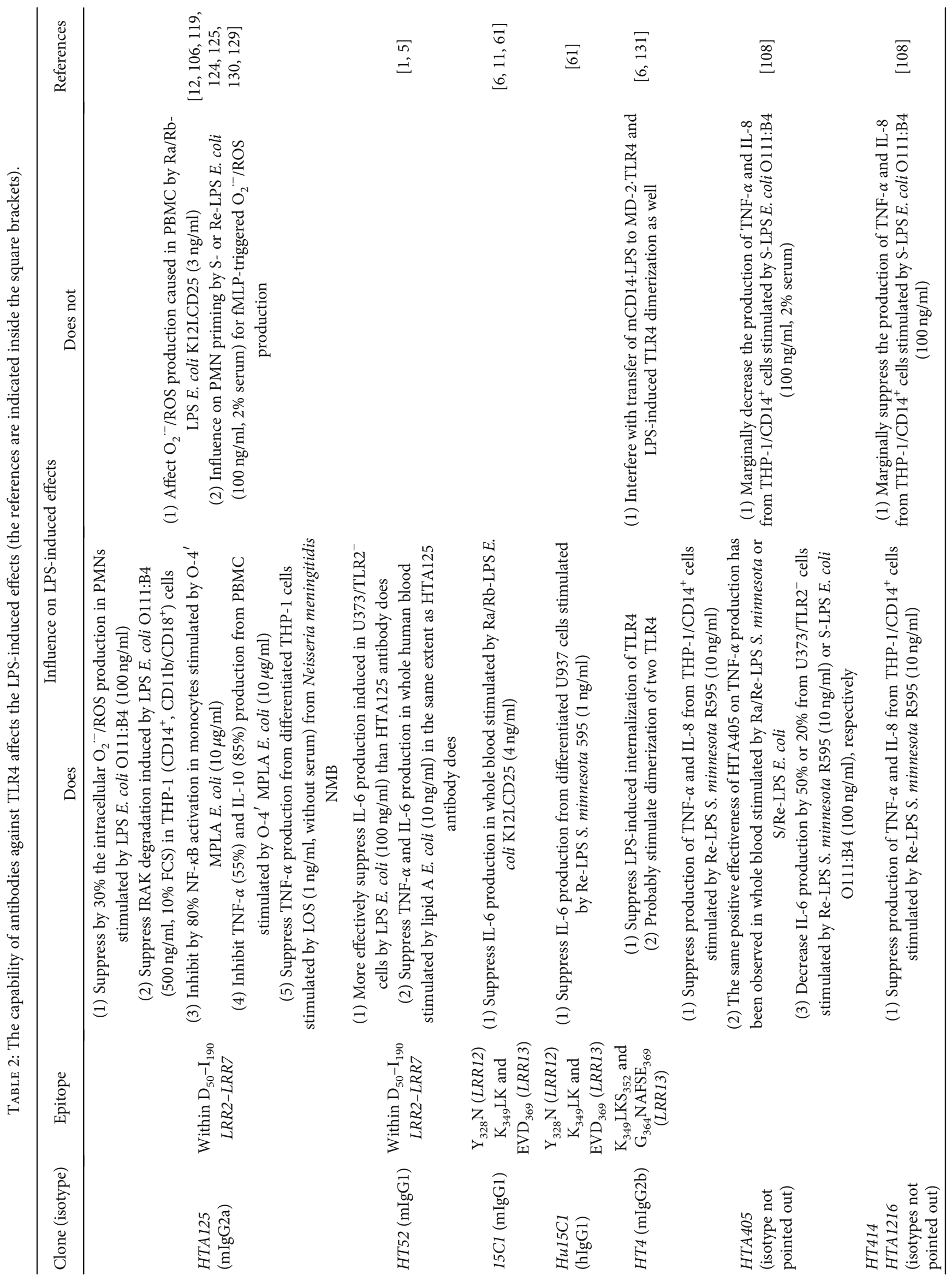


The therapeutic effectiveness of humanized antiTLR4 ${ }^{\text {NI-0101 }}$ antibody has been already evaluated ex vivo and in vivo in the absence or presence of systemic LPS challenge (acute inflammation) [7, 9]. The other effective neutralizing anti-TLR $4^{\mathrm{WN} 1222-5}$ antibody mimics the site of TLR4, recognizing an inner core structure of LPS from most infectious bacteria regardless of the presence of $\mathrm{O}$ polysaccharide (O-antigen) and prevents LPS binding to target cells in the bloodstream [136].

7.5. Impact of CD32 in Effectiveness of IgG Antibodies. Antigenic recognition of CD32A by anti-CD $32^{\mathrm{IV} .3} \mathrm{Fab} / \mathrm{F}\left(\mathrm{ab}^{\prime}\right)_{2}$ fragments recognizing the $\mathrm{F}_{132} \mathrm{SHLDP}_{137}$ sequence does not cause $\mathrm{Ca}^{2+}$ mobilization, upregulation of p38 and ERK MAPK kinases, and intracellular production of $\mathrm{H}_{2} \mathrm{O}_{2}$ /ROS (scopoletin) [137]. The other anti-CD32 ${ }^{\mathrm{CIKM} 5} \mathrm{Fab} / \mathrm{F}\left(\mathrm{ab}^{\prime}\right)_{2}$ are also unable to induce $\mathrm{Ca}^{2+}$ mobilization when crosslinking by secondary $\mathrm{F}\left(\mathrm{ab}^{\prime}\right)_{2}$ fragments is omitted [64, 78]. Targeting CD32 by anti-CD $32^{\mathrm{AT}-10} \mathrm{~F}\left(\mathrm{ab}^{\prime}\right)_{2}$ inhibits constitutive and fMLP-triggered $\mathrm{O}_{2}{ }^{-} / \mathrm{ROS}$ (luminol) production by PMNs $[134,138]$. In PMNs, a small rise in intracellular free $\mathrm{Ca}^{2+}$ has been induced also by anti-CD $32{ }^{\mathrm{CIKM} 5} \mathrm{Fc}^{\mathrm{mIgG} 1}$ antibody but it was not associated with $\mathrm{O}_{2}{ }^{--}$release (SOD-inhibitable reduction of ferricytochrome C) $[64,78]$. Antigenic recognition of $\mathrm{CD} 32 \mathrm{~A}$ by anti-CD $32^{\mathrm{AT}-10}$ Fab fragments recognizing an epitope located near or within IgG-binding site fails to activate differentiated monocytic THP-1 cells [134, 138]. Recent findings however have indicated that antigenic CD32 recognition by anti-CD32 $2^{\text {IV.3/AT-10 }} \mathrm{Fab} / \mathrm{F}\left(\mathrm{ab}^{\prime}\right)_{2}$ induced ITAMi signaling [134]. It has been shown that engagement of CD32 by anti-CD32 $2^{\mathrm{AT}-10} \mathrm{~F}\left(\mathrm{ab}^{\prime}\right)_{2}$ stimulates transient recruitment of tyrosine kinase ${ }^{2 \mathrm{SH} 2} \mathrm{Syk} / \mathrm{p} 72^{\mathrm{Tyr}}$ to cytoplasmic domain of CD32A followed by incomplete phosphorylation of the ITAM leading to the inhibitory ITAMi conformation. As a result, activated ITAMi allows tyrosine phosphorylation of SHP-1 (protein tyrosine phosphatase) followed by inhibition of the major intracellular signaling players of immune cells such as guanine nucleotide exchange factor Vav-1 (RacGEF) and IRAK-1 kinase that are both involved in $\mathrm{O}_{2}{ }^{-}$/ $\mathrm{ROS}$ and cytokine production. Thus, blockage of Vav-1 in human PMNs can abrogate association of p $67^{\text {phox }}$ with $\mathrm{NADPH}$ oxidase thereby suppressing $\mathrm{O}_{2}$. - /ROS production [134]. This suppressive effect of CD32A and mIgG1 might be reversed by LPS-induced assembly and stabilization of TLR4, CD11b/CD18, and Fc $\gamma$ Rs in lipid rafts followed by the activation of classical ITAM signaling $[11,41,44,79,139]$. Since PMNs express very low levels of $\mathrm{CD} 32 \mathrm{~B}$, an impact of its involvement in the inhibitory effectiveness of mIgG1 antibodies should be negligible [140].

Antigenic recognition of CD16 by anti-CD $16^{3 \mathrm{G} 8}$ $\mathrm{Fab} / \mathrm{F}\left(\mathrm{ab}^{\prime}\right)_{2}$ despite the minor rise in free $\mathrm{Ca}^{2+}$ does not cause activation of p38 and ERK MAPK kinases nor actin polymerization and intracellular $\mathrm{H}_{2} \mathrm{O}_{2}$ /ROS production (DHR) [137, $141,142]$. In addition, fMLP-triggered ROS production (luminol) is also not influenced by prior PMN exposure to anti-CD16 ${ }^{3 \mathrm{G} 8} \mathrm{~F}\left(\mathrm{ab}^{\prime}\right)_{2}$ [143]. Thus, it can be concluded that targeting CD16 by anti-CD16 ${ }^{3 \mathrm{G} 8} \mathrm{Fab} / \mathrm{F}\left(\mathrm{ab}^{\prime}\right)_{2}$ is unable to prime or upregulate intracellular $\mathrm{O}_{2}{ }^{--} / \mathrm{ROS}$ production in
PMNs. By contrast, in monocytes, antibody-dependent association of CD32 with CD16 (CD16 $\leftarrow$ anti$\left.\mathrm{CD} 16^{3 \mathrm{G} 8} \mathrm{Fc}^{\mathrm{mIgG} 1} \rightarrow \mathrm{CD} 32\right)$ in the plane of plasma membrane is able to initiate intracellular signaling events leading to generation of Ins $(1,4,5) \mathrm{P}_{3}, \mathrm{DAG}$, and $\mathrm{Ca}^{2+}$ mobilization but not to calcium influx $[64,78]$.

Now, the impact of $\mathrm{mIgG}$ subclasses in activation of human immune cells has been revealed. It has been shown in PMNs that mIgG2a is unable to induce protein tyrosine phosphorylation and substantial rise in intracellular free $\mathrm{Ca}^{2+}[70,144]$. When we have used mIgG1 or mIgG2a and unprimed PMNs, only marginal fMLP-triggered $\mathrm{O}_{2}{ }^{-} / \mathrm{ROS}$ production was observed [12-14]. Neither anti$\mathrm{CD} 11 \mathrm{~b}^{60.1 / 44} \mathrm{Fc}{ }^{\mathrm{mIgG} 1}$ nor anti-CD $11 \mathrm{~b} / \mathrm{CD} 18^{\mathrm{IB} 4} \mathrm{Fc}{ }^{\mathrm{mIgG} 2 \mathrm{a}}$ antibodies are not able to induce $\mathrm{Ca}^{2+}$ mobilization in PMNs $[70,145,146]$. Targeting CD11b/CD18 on freshly prepared PMNs by anti-CD $11 b^{\text {Leu-15 }} \mathrm{Fc}^{\text {mIgG2a }}$ antibody does not stimulate considerable intracellular $\mathrm{O}_{2}{ }^{-}$/ ROS production $[62,63,147]$. Anti-CD $11 \mathrm{~b} / \mathrm{CD} 18^{\mathrm{IB}} \mathrm{Fc}^{\mathrm{mIgG} 2 \mathrm{a}}$ or anti$\mathrm{CD} 11 \mathrm{~b}^{44 \mathrm{a}} \mathrm{Fc}^{\mathrm{mIgG} 1}$ antibodies cause negligible intracellular $\mathrm{H}_{2} \mathrm{O}_{2} /$ ROS (DHR) production in PMNs and even to a lesser extent than agonistic anti-CD $11 \mathrm{~b}^{\mathrm{VIM} 12} \mathrm{Fc}^{\mathrm{mIgG} 1}$ antibody [147]. Antibody-dependent association of CD11b/CD18 with CD64/CD32 (CD11b $\leftarrow$ anti-CD11b ${ }^{\text {Leu- }}$ ${ }^{15} \mathrm{Fc}^{\mathrm{mIgG} 2 \mathrm{a}} \rightarrow \mathrm{CD} 64 / \mathrm{CD} 32$ or $\mathrm{CD} 11 \mathrm{~b} \leftarrow$ anti-CD11b ${ }^{44 \mathrm{a}} \mathrm{Fc}-$ $\mathrm{mIgG} 1 \rightarrow \mathrm{CD} 32$ or $\mathrm{CD} 11 \mathrm{~b} / \mathrm{CD} 18 \leftarrow$ anti-CD $11 \mathrm{~b} / \mathrm{CD} 18{ }^{\mathrm{IB} 4} \mathrm{Fc}-$ mIgG2a $\rightarrow$ CD64/CD32) is also unable to stimulate considerable intracellular $\mathrm{O}_{2}^{--}$/ROS production in PMNs. These data, including ours, may suggest that neither mIgG2a nor mIgG1 are able to stimulate substantial rise in intracellular free $\mathrm{Ca}^{2+}$ and ROS production in freshly isolated PMNs. It is necessary to note that agonistic anti$\mathrm{CD} 11 \mathrm{~b}^{\mathrm{VIM} 12} \mathrm{Fc}^{\mathrm{mIgG} 1}$ antibody recognizing the $\mathrm{CD} 11 \mathrm{~b}$ lectin site causes intracellular $\mathrm{H}_{2} \mathrm{O}_{2} / \mathrm{ROS}$ production in $\mathrm{PMNs}$ to the same extent as fMLP [147].

By contrast, in macrophage-like Mono Mac 6 cells, LPS-induced production of TNF- $\alpha$ and IL-10 has been potentiated by mIgG2a, while production of IL- $1 \beta$ has been suppressed [62]. A line of other data indicates that LPS-induced activation of IRAK and production of TNF- $\alpha$ and IL- 8 from differentiated human monocytic THP-1 cells are not influenced by mIgG2a [106, 124, 127].

7.6. Upregulation of PMN Sensitivity to mIgG2a after IFN- $\gamma$ Priming. IFN- $\gamma$ is the most potent priming agent released in bloodstream during LPS-induced inflammation $[15,16$, 148, 149]. Thus, during inflammation, the expression of CD64 on PMN is upregulated, while CD32 is unaffected or downregulated $[62,63]$. As a result, IFN- $\gamma$-primed PMNs $(20 \mathrm{~h})$ acquire the ability to respond to mIgG2a antibodies such as anti-CD $11 \mathrm{~b}^{\mathrm{Leu}-15} \mathrm{Fc}^{\mathrm{mIgG} 2 \mathrm{a}}$ by marked intracellular $\mathrm{O}_{2}{ }^{--} /$ROS production $(\mathrm{DCFDA})\left(\mathrm{CD} 11 \mathrm{~b} \leftarrow\right.$ anti-CD $11 \mathrm{~b}^{\text {Leu- }}$ $\left.{ }^{15} \mathrm{Fc}^{\mathrm{mIgG} 2 \mathrm{a}} \rightarrow \mathrm{CD} 64\right)$ [63]. However, IFN- $\gamma$ does not confer on PMNs the capability to generate $\mathrm{O}_{2}{ }^{-}$/ $\mathrm{ROS}$ in response to mIgG1 antibodies such as anti-CD11b ${ }^{\mathrm{VIM} 12} \mathrm{Fc}^{\mathrm{mIgG} 1}$ or anti-CD $11 b^{5 \mathrm{~A} 4 . \mathrm{C} 5} \mathrm{Fc}^{\mathrm{mIgG1}} \quad\left(\mathrm{CD} 1 \mathrm{~b} \leftarrow \mathrm{anti}^{\mathrm{CD}} 11 \mathrm{~b}{ }^{\text {VI- }}\right.$ $\left.{ }^{\mathrm{M} 12 / 5 \mathrm{~A} 4 . \mathrm{C} 5} \mathrm{FC}^{\mathrm{mIgG1}} \rightarrow \mathrm{CD} 32\right)$, which is in agreement with IFN- $\gamma$-dependent CD32 downregulation [62, 63]. Thus, we concluded that only primed PMNs would be sensitive to 
mIgG2a antibodies, while freshly isolated PMNs are marginally responsive to mouse antibodies with IgG2a or IgG1 isotypes (regardless of epitope specificity).

In humans, as it has been revealed in vivo, the LPS administration causes an initial rapid decline in the absolute PMN counts at $1 \mathrm{~h}$ followed by an increase that reaches a maximum at $6 \mathrm{~h}$ and then declines at $22 \mathrm{~h}$ to basal levels. In addition, LPS injection induces biphasic CD64 upregulation on circulating PMNs. The first phase has been observed after $1 \mathrm{~h}$ of LPS challenge, while the second started at $6 \mathrm{~h}$ and reached a maximum at $22 \mathrm{~h}$ [148].

By contrast, freshly isolated monocytes constitutively express high levels of surface CD64 [61, 62] and respond to anti-CD11b ${ }^{\mathrm{VIM12}} \mathrm{Fc}^{\mathrm{mIgG1}}$ or anti-CD11 ${ }^{\mathrm{Leu}-15} \mathrm{Fc}^{\mathrm{mIgG2a}}$ antibodies by intracellular ROS production (DCFDA). For example, anti-CD $11 b^{\mathrm{Leu}-15} \mathrm{Fc}^{\mathrm{mIgG} 2 \mathrm{a}}$ antibody causes an increase in ROS production in monocytes of all responders, while agonistic anti-CD $11 \mathrm{~b}^{\mathrm{VIM} 12} \mathrm{Fc}^{\mathrm{mIgG1}}$ in $60 \%$ only. When anti$\mathrm{CD} 11 \mathrm{~b}^{\mathrm{VIM} 12} \mathrm{Fc}^{\mathrm{mIgG1}}$ antibody has been devoid of the $\mathrm{Fc}$ arms, its ability to stimulate ROS (DCFDA) production in freshly isolated monocytes was diminished [63]. Thus, the agonistic activity of anti-CD $11 \mathrm{~b}^{\mathrm{VIM} 12} \mathrm{Fc}^{\mathrm{mIgG1}}$ antibody represents the cumulative effect of epitope specificity and capability to engage CD64/CD32 receptors.

The engagement of $\mathrm{CD} 64$, and $\mathrm{CD} 32$ to a lesser extent, by anti-TLR4 ${ }^{\mathrm{HTA} 125} \mathrm{Fc}^{\mathrm{mIgG} 2 \mathrm{a}}$ antibody has been already revealed using macrophage-like Mono Mac 6 cells $($ CD32 > CD64). Mouse IgG2a inhibits most effectively the binding of antiTLR4 ${ }^{\mathrm{HTA125}} \mathrm{Fc}^{\mathrm{mIgG} 2 \mathrm{a}}$ antibody to Mono Mac 6 cells, while mIgG1 or mIgG2b reveals no significant effect. Further, the binding of anti-TLR $4^{\mathrm{HTA} 125}$ antibody to Mono Mac 6 cells has been most effectively prevented by anti-CD64 ${ }^{10.1} \mathrm{Fc}^{\mathrm{mIgG1}}$ antibody by contrast to anti-CD32 ${ }^{\mathrm{FL} 18.26} \mathrm{Fc}^{\mathrm{mIgG} 2 \mathrm{~b}}$ antibody. Targeting CD16 by anti-CD16 $6^{3 \mathrm{G} 8} \mathrm{Fc}^{\mathrm{mIgGl}}$ antibody does not influence significantly on anti-TLR ${ }^{\mathrm{HTA} 125}$ binding to Mono Mac 6 cells [62]. Based on these findings, the high affinity of human CD64 and moderate affinity of human CD32 for the constant Fc arm of mIgG2a antibodies can be concluded $[62,63]$. These results indicate also that specific Fab or $\mathrm{F}\left(\mathrm{ab}^{\prime}\right)_{2}$ fragments against cell surface receptors would be most appropriate and safe for applying in "antibody"-based therapy.

In summary, the major mechanisms underlying the inhibitory effectiveness of anti-TLR4 antibodies follow (1) an interference with TLR4 binding to CD14.LPS and LPS-MD-2, (2) inhibition of ligand- (LPS-) induced conformational changes that are indispensable for TLR4 signaling (HT4, HT52, 15C1, and Hu15C1) [1, 11, 61], (3) prevention of ligand-induced TLR4 partitioning into lipid rafts and its subsequent internalization (HT4, HT52, and Hu15C1) [1], and (4) engagement of $\mathrm{Fc} \gamma \mathrm{Rs}(\mathrm{CD} 32 / \mathrm{CD} 64)$ followed by ITAMi-initiated inhibitory signaling interfering with positive signaling induced by other receptors on the same cell (CD14, MD-2.TLR4, and CD11b/CD18) $[61,134]$.

\section{CD11b/CD18 and Their Signaling Partners}

Macrophage-1 antigen (Mac-1, $\alpha_{\mathrm{M}} \beta_{2}$, or CD11b/CD18) is a complement receptor (CR3). It consists of noncovalently linked CD11b (integrin $\alpha_{\mathrm{M}}$ ) and CD18 (integrin $\beta_{2}$ ) subunits. Integrins regulate important leukocyte functions including adhesion, migration, proteolysis, phagocytosis, and oxidative (respiratory) burst [150]. In resting PMNs, integrins are maintained in a conformationally inactive state and are unable to bind their ligands [151]. On cell stimulation, "inside-out" signaling originating from nonintegrin cell surface receptors such as FPR1, Fc $\gamma$ Rs, or TLR4 leads to vast conformational changes in CD11b/CD18, but not directly to receptor clustering (integrin redistribution in the plane of plasma membrane) [42, 52]. Thus, only "inside-out" primed integrins exhibit increased ligand-binding avidity and initiate "outside-in" signaling by themselves. $\mathrm{CD} 11 \mathrm{~b} / \mathrm{CD} 18$ has been detected in the LPS-induced "receptor cluster" on monocytes and can act as a signaling partner for such receptors as FPR1 and CD14 [44, 106, 150, 152, 153]. CD11b/CD18 can be found also in association with $\mathrm{F} c \gamma \mathrm{Rs}$, but the consequences of these functional interactions are not fully understood. The functional association of the GPI-anchored form of CD16 $\left({ }^{\mathrm{PMN}} \mathrm{CD} 16 \mathrm{~B}{ }^{\mathrm{GPI}}\right)$ with $\mathrm{CD} 11 \mathrm{~b} / \mathrm{CD} 18$ is mediated by the lectin-binding site of the latter $[147,151,153-155]$. The mechanisms by which $\mathrm{CD} 1 \mathrm{~b} / \mathrm{CD} 18$ regulates leukocyte functions such as respiratory burst are still poorly understood.

Like other $\beta_{2}$ integrins, CD11b consists of a short cytoplasmic tail, single transmembrane domain, and long extracellular domain. The extracellular domain of CD11b is composed of seven repeats. The V to VII repeats are similar to the divalent cation-binding "EF-hand" motif. The II and III repeats are separated by the I (inserted) domain that is known also as $\alpha \mathrm{A} / \mathrm{I}$-domain [156]. The effectiveness of anti-CD11b/CD18 antibodies against LPS-induced effects is listed in Table 3.

8.1. Targeting the CD11b $\alpha A / I-D o m a i n$. Antigenic recognition of $\mathrm{CD} 11 \mathrm{~b} / \mathrm{CD} 18$ by anti-CD11b ${ }^{44} \mathrm{Fab}$ recognizing $\alpha \mathrm{A} / \mathrm{I}$-domain does not lead to considerable changes in conformation of CD11b/CD18 nor to activation of "outside-in" signaling $[161,162]$. However, full anti-CD $11 b^{44 a}$ or anti$\mathrm{CD} 11 \mathrm{~b} / \mathrm{CD} 18^{\mathrm{IB} 4} \mathrm{Fc}^{\mathrm{mIgG} 2 \mathrm{a}}$ antibodies induce epitope exposition by $\mathrm{CD} 11 \mathrm{~b}$ that is recognized by anti-CD $11 \mathrm{~b}^{\mathrm{VIM} 12} \mathrm{Fc}$ mIgG1 antibody [147]. This effect may be explained by antibody-dependent association of CD11b/CD18 with Fc $\gamma$ Rs. So, 44a or IB4 antibodies are able to induce "outside-in" signaling followed by "inside-out" signaling leading to further conformational changes in CD11b/CD18.

8.2. Targeting the C-Terminal Lectin Domain of CD11b. Antigenic recognition of the $\mathrm{C}$-terminal lectin domain of $\mathrm{CD} 11 \mathrm{~b}$ $\left(\mathrm{AA}_{614-682}\right)$ located near the cell membrane by anti$\mathrm{CD} 11 \mathrm{~b}^{\mathrm{OKM} 1} \mathrm{Fab}$ or $\mathrm{F}\left(\mathrm{ab}^{\prime}\right)_{2}$ does not induce PMN intracellular $\mathrm{H}_{2} \mathrm{O}_{2} / \mathrm{ROS}$ (scopoletin) production [137]. In PMNs, neither anti-CD $11 b^{60.1 / 44} \mathrm{Fc}^{\mathrm{mIgG1}}$ nor anti-CD $11 \mathrm{~b} / \mathrm{CD} 18^{\mathrm{IB} 4} \mathrm{Fc}^{\mathrm{mIgG} 2 \mathrm{a}}$ antibodies cause $\mathrm{Ca}^{2+}$ mobilization $[70,145,146]$. The same result was obtained during cell response to anti$\mathrm{CD} 18^{\mathrm{MHM} 23} \mathrm{Fc}^{\mathrm{mIgG1}}$ or anti-CD $11 \mathrm{~b} / \mathrm{CD} 18^{60.3} \mathrm{Fc}^{\mathrm{mIgG2a}}$ antibodies regardless of isotype differences [78, 145]. Further, intracellular $\mathrm{H}_{2} \mathrm{O}_{2} / \mathrm{ROS}$ (DHR) triggered in PMNs by antibody-dependent association of CD32 with CD11b/CD18 
TABLE 3: The capability of antibodies against CD11b/CD18 affects the LPS-induced effects (the references are indicated inside the square brackets).

\begin{tabular}{llcc}
\hline $\begin{array}{l}\text { Clone } \\
\text { (isotype) }\end{array}$ & Epitope & Does & Influence on LPS-induced effects \\
\hline
\end{tabular}

(1) Inhibit binding of LPS E. coli O111:B4 $(10 \mathrm{ng} / \mathrm{ml}$, $10 \%$ FCS) to human PBMC

(2) Inhibit PMN priming by LPS E. coli O55:B5

(100 ng/ml, 1\% serum) for fMLP-triggered $\mathrm{O}_{2}{ }^{-{ }^{-}} / \mathrm{ROS}$ production

$\begin{array}{lc}\text { OKM-1 } & \mathrm{CD} 11 \mathrm{~b} \\ \text { (mIgG2b) } & \mathrm{AA}_{614-682} \\ \text { (lectin site) }\end{array}$

(1) Increase TNF- $\alpha$ production from monocytes stimulated by LPS $S$. minnesota $(1 \mathrm{ng} / \mathrm{ml}$, without serum)
(3) Inhibit protein (41 and $42 \mathrm{kDa}$ ) tyrosine phosphorylation in macrophages stimulated by Re-

LPS S. minnesota R595 (1 ng/ml, human serum)

$[63,91,99$, $100,104,105$, $157,158]$

(4) Influence on $\mathrm{O}_{2}{ }^{-} / \mathrm{ROS}$ production induced by $\mathrm{Re}$ LPS E. coli ( $1 \mathrm{ng} / \mathrm{ml}, 5 \%$ serum) in human monocytes

(5) Influence on TNF- $\alpha$ production from human PBMC stimulated by LPS E. coli O111:B4 (100 ng/ml, $10 \%$ serum)

(1) Suppress macrophage interaction with bovine erythrocytes opsonized by Re-LPS S. minnesota R595

$\begin{array}{cc}904 & \mathrm{AA}_{74-316} \\ (\mathrm{mIgG} 2 \mathrm{~b}) & (\alpha \mathrm{A} / \mathrm{I}- \\ & \text { domain })\end{array}$

ICRF 44 (mIgG1)

$\mathrm{CD} 11 \mathrm{~b}$

\author{
IB4 \\ (mIgG2a) CD11b/CD18
}

(1) Increase TNF- $\alpha$ production from monocytes stimulated by LPS $S$. minnesota $(1 \mathrm{ng} / \mathrm{ml}$, without serum)
$[159,160]$

(1) Affect PMN priming by S- or Re-LPS E. coli (100 ng/ml, 2\% serum) for fMLP-triggered $\mathrm{O}_{2}{ }^{-{ }^{-}} / \mathrm{ROS}$ production

(1) Inhibit binding of LPS E. coli O111:B4 (100 ng/ml, $10 \%$ serum) to human PBMC and TNF- $\alpha$ production

(2) Influence on activation of p38 MAPK during PMN priming by LPS E. coli O55:B5 ( $5 \mathrm{ng} / \mathrm{ml})$ for $[77,99,157]$ fMLP-triggered $\mathrm{O}_{2}{ }^{-} / \mathrm{ROS}$ production
$\left(\mathrm{CD} 11 \mathrm{~b} / \mathrm{CD} 18 \leftarrow\right.$ anti-CD11b $\left.{ }^{44 / \mathrm{IB} 4} \mathrm{Fc}{ }^{\mathrm{mIgG} 1 / \mathrm{mIgG} 2 \mathrm{a}}\right)$ was less pronounced than that in response to agonistic anti$\mathrm{CD}_{11 \mathrm{~b}}{ }^{\mathrm{VIM} 12} \mathrm{Fc}^{\mathrm{mIgG1}}$ antibody [147]. Thus, it can be concluded that simple antibody-dependent association of CD11b/CD18 with CD32 (regardless of epitope specificity) is not enough to initiate significant agonistic (activating) signaling events and $\mathrm{H}_{2} \mathrm{O}_{2} /$ ROS production in PMNs, whereas to induce sufficient intracellular signaling by IgG1 antibodies, targeting of a particular epitope on CD11b is required. In fact, when agonistic anti-CD $11 b^{V I M 12} \mathrm{Fc}^{\mathrm{mIgG1}}$ antibody recognizing the CD11b lectin site had been employed to PMNs, "outside-in" signaling, clustering of activated CD11b/CD18, upregulation of PI3K and $\mathrm{PKB} /$ Akt signaling pathways, $\mathrm{Ca}^{2+}$ mobilization, and actin polymerization were all realized, but the $\mathrm{Raf} \rightarrow \mathrm{ME}$ $\mathrm{K} 1 / 2 \rightarrow$ ERK1/2 signaling pathway was not upregulated [163]. Agonistic anti-CD $11 \mathrm{~b}^{\mathrm{VIM} 12} \mathrm{Fc}^{\mathrm{mIgG1}}$ antibody prevents association of CD11b/CD18 with $\mathrm{CD}_{16 \mathrm{~B}}{ }^{\mathrm{GPI}}$ [163] but nevertheless induces PMNs for generation of $\mathrm{H}_{2} \mathrm{O}_{2} / \mathrm{ROS}$ (DHR) to the same extent as fMLP. Anti-CD11 $b^{\text {VIM12 }} \mathrm{Fc}^{\mathrm{mIgG} 1}$-dependent production of $\mathrm{H}_{2} \mathrm{O}_{2}$ / ROS (DHR) exceeds that induced by IB4 or 44a antibodies [147]. Taking these facts into consideration, it may be suggested that CD11b/CD18-dependent "outside-in" signaling would be successfully realized when CD11b lectin domain is docked (thus, CD11b/CD18 is primed) by other appropriate GPI-anchored protein on the same cell. In PMNs, "outside-in" signaling is also initiated by $\mathrm{CD} 11 \mathrm{~b} / \mathrm{CD} 18$ that has been clustered in the response to
anti-CD11 $\mathrm{b}^{2 \mathrm{LPM} 19 \mathrm{c}} \mathrm{F}\left(\mathrm{ab}^{\prime}\right)_{2}$ recognizing $\alpha \mathrm{A} / \mathrm{I}$-domain. The same effect had been observed when whole anti$\mathrm{CD} 11 \mathrm{~b}^{2 \mathrm{LPM19c}} \mathrm{Fc}^{\mathrm{mIgG1}}$ antibody was used. Unexpectedly, monovalent anti-CD $11 b^{2 \mathrm{LPM} 19 \mathrm{C}} \mathrm{Fab}$ is unable to produce such agonistic activity [158]. These results clearly show that agonistic activity of anti-CD11b antibodies is determined by $\mathrm{F}\left(\mathrm{ab}^{\prime}\right)_{2}$ epitope specificity. Moreover, $\mathrm{F}\left(\mathrm{ab}^{\prime}\right)_{2}$ can potentially bind two targets leading to close proximity of two integrin molecules that mimic receptor crosslinking [164].

In PMNs, generation of $\mathrm{H}_{2} \mathrm{O}_{2} / \mathrm{ROS}$ (DHR) induced by anti-CD $11 b^{\text {VIM12 }} \mathrm{Fc}^{\mathrm{mIgG1}}$ antibody is not diminished by prior cell exposure to anti-CD $11 b^{44 a} \mathrm{Fc}^{\mathrm{mIgG1}}$ or anti$\mathrm{CD} 11 \mathrm{~b} / \mathrm{CD} 18^{\mathrm{IB} 4} \mathrm{Fc}^{\mathrm{mIgG} 2 \mathrm{a}}$ antibodies. It necessary to note that sequential treatment of PMNs in whole blood by anti$\mathrm{CD} 11 \mathrm{~b} / \mathrm{CD} 18^{\mathrm{IB} 4} \mathrm{Fc}^{\mathrm{mIgG} 2 \mathrm{a}}$ and anti-CD $11 \mathrm{~b}^{\mathrm{VIM} 12} \mathrm{Fc}^{\mathrm{mIgG} 1}$ antibodies led to more pronounced generation of $\mathrm{H}_{2} \mathrm{O}_{2} / \mathrm{ROS}$ (DHR) than treatment with anti-CD $11 b^{44 a} \mathrm{Fc}^{\mathrm{mIgG1}}$ combined with anti-CD11b ${ }^{\mathrm{VIM12}} \mathrm{Fc}^{\mathrm{mIgG1}}$ antibody [147]. This result may be explained by the fact that anti-CD $11 \mathrm{~b} / \mathrm{CD} 18^{\mathrm{IB} 4} \mathrm{Fc}$ mIgG2a antibody is able to potentiate the binding of anti$\mathrm{CD} 11 \mathrm{~b}^{\mathrm{VIM} 12} \mathrm{Fc}^{\mathrm{mIgG1}}$ antibody to $\mathrm{CD} 11 \mathrm{~b} / \mathrm{CD} 18$ in addition to their ability to affect both subunits of CD11b/CD18. Thus, anti-CD $11 \mathrm{~b} / \mathrm{CD} 18^{\mathrm{IB} 4} \mathrm{Fc}^{\mathrm{mIgG} 2 \mathrm{a}}$ antibody, besides binding to $\mathrm{CD} 11 \mathrm{~b} / \mathrm{CD} 18$, can also engage other $\beta_{2}$ integrins via the common CD18 subunits (CD11a/CD18 and CD11c/CD18). Such broad targeting of $\beta_{2}$ integrins could provide sufficient 
signals for intracellular $\mathrm{H}_{2} \mathrm{O}_{2}$ / ROS generation (DHR). This conclusion is supported by the fact that antigenic recognition of $\mathrm{CD} 11 \mathrm{~b} / \mathrm{CD} 18$ by anti-CD11b/CD $18^{\mathrm{IB} 4} \mathrm{~F}\left(\mathrm{ab}^{\prime}\right)_{2}$ induces $\mathrm{Ca}^{2+}$ mobilization to a similar extent as whole anti$\mathrm{CD} 11 \mathrm{~b} / \mathrm{CD} 18^{\mathrm{IB} 4} \mathrm{Fc}^{\mathrm{mIgG} 2 \mathrm{a}}$ antibody [165].

In PMNs, generation of $\mathrm{ROS} / \mathrm{H}_{2} \mathrm{O}_{2}$ (DHR) induced by anti-CD $11 b^{\text {VIM12 }} \mathrm{Fc}^{\text {mIgG1 }}$ antibody can be blocked almost completely by prior cell exposure to anti-CD $32^{\mathrm{IV} \cdot 3} \mathrm{Fc}^{\mathrm{mIgG} 2 \mathrm{~b}}$ antibody [160]. Thus, unlike monocytes, CD32 receptor on $\mathrm{PMNs}$ is involved in CD11b/CD18-induced generation of $\mathrm{ROS} / \mathrm{H}_{2} \mathrm{O}_{2}$ (DHR) in the response to anti-CD $11 \mathrm{~b}^{\mathrm{VIM} 12} \mathrm{Fc}^{\mathrm{mIgG} 1}$ antibody (CD11b/CD18 $\leftarrow$ anti-CD $\left.11 b^{\text {VIM12 }} \mathrm{Fc}^{\mathrm{mIgG} 1} \rightarrow \mathrm{CD} 32\right)$. Therefore, it has been supposed that association of CD11b/CD18 with CD32 is required for ROS generation during $\mathrm{PMN}$ response to anti-CD $11 \mathrm{~b}^{\mathrm{VIM} 12} \mathrm{Fc}{ }^{\text {mIgG1 }}$ antibody [147]. Ortiz-Stern and Rosales [73] have shown that CD32 and CD11b/CD18 are uniformly distributed and not colocalized on the surface of unstimulated PMNs. A similar observation has been made for ${ }^{\mathrm{PMN}} \mathrm{CD} 16 \mathrm{~B}^{\mathrm{GPI}}$ which is also uniformly distributed across the cell surface and is not colocalized with CD32 in unstimulated PMNs [73].

By contrast to PMNs, in monocytes, a close spatial proximity between CD11b/CD18 and CD32/CD64 has been suggested by Gadd et al. [63]. These authors have observed that anti-CD $11 b^{\text {VIM12 }} \mathrm{Fc}^{\text {mIgG1 }}$ antibody interferes sterically with anti-CD $32^{\mathrm{IV} .2} \mathrm{Fc}^{\mathrm{mIgG} 2 \mathrm{~b}}$ antibody for binding to $\mathrm{CD} 32$ on monocytes, but not on PMNs [63]. Interestingly, in their study, anti-CD11b ${ }^{\mathrm{VIM} 12} \mathrm{Fc}^{\mathrm{mIgG1}}$ antibody had been unable to induce intracellular ROS (DCFDA) generation in PMNs as they did in monocytes [63, 147].

\subsection{Anti-CD11b/CD18 Antibodies in Therapeutic} Medications. In the light of data presented here, the effectiveness of anti-CD11b/CD18 antibodies against LPS-induced effects should be discussed. It has been shown that CD11b/CD18 has a site recognizing LPS carbohydrates, namely, $\mathrm{N}$-acetyl-D-glucosamine (GlcNAc) and mannose. In addition, CD11b/CD18 binds truncated LPS glycoforms such as Re-LPS [153-155]. Two putative LPS-binding sites within the $\mathrm{CD} 18 \beta \mathrm{A}$ region $\left(\mathrm{AA}_{216-248}, 266-318\right)$ had been proposed earlier [166]. It was found that Re-LPS from Salmonella minnesota is bound through cationic interactions by the $\beta \mathrm{A}_{266-318}$-exposed CD18 sequence, while another $\beta \mathrm{A}_{216-248}$ sequence probably utilizes other interactions like hydrophobic ones [166]. Thus, it is not excluded that 3-deoxy-Dmanno-octulosonic acid (KDO), the inner core sugar of almost all LPS molecules, may be involved in LPS recognition by CD18 [153, 155, 159, 160]. However, neither LPS binding to PBMC nor LPS-induced PMN priming for fMLPtriggered ROS production has been blocked by antiCD11b ${ }^{\text {OKM1 }} \mathrm{Fc}^{\mathrm{mIgG} 1}$ antibody $[91,99,100,104]$. A similar result has been obtained in our work [13] where we used anti-CD $11 b^{\text {ICRF44 }} \mathrm{Fc}^{\mathrm{mIgG1}}$ antibody. This antibody binds probably to $\alpha \mathrm{A} / \mathrm{I}$-domain of CD11b $\left(\mathrm{AA}_{201-217}, 245-261\right)$ in a manner independent of inactive or active CD11b/CD18 state $[158,162,167]$. Thus, it may be concluded that targeting the $\alpha \mathrm{A} / \mathrm{I}$-domain of CD11b by anti-CD $11 \mathrm{~b}^{\mathrm{ICRF} 44} \mathrm{Fc}{ }^{\mathrm{mIgG} 1}$ or the $\mathrm{CD} 11 \mathrm{~b}$ lectin site by anti-CD11 ${ }^{\mathrm{OKM1}} \mathrm{Fc}^{\mathrm{mIgG1}}$ antibodies is unable to suppress significantly LPS-dependent PMN prim- ing for fMLP-triggered $\mathrm{O}_{2}{ }^{-}$/ROS production [13, 91, 99, $100,104]$. From the data presented here, we can, however, not exclude that other CD11b/CD18 sites might be involved in LPS recognition. The effectiveness of anti-CD $11 b^{44} \mathrm{Fc}{ }^{\mathrm{mIgG} 1}$ antibodies as suppressors of LBP.LPS-dependent PMN priming for fMLP-triggered $\mathrm{O}_{2}{ }^{-} /$ROS production is less pronounced than that of anti-CD $14{ }^{3 \mathrm{C} 10} \mathrm{Fc}^{\mathrm{mIgG} 2 \mathrm{~b}}$ antibody [90]. Thus, targeting CD14 by appropriate antibodies would be more effective in comparison to targeting CD11b/CD18 or TLR4. Moreover, it has been shown that CD11b/CD18 interacts more avidly with aggregated but not monomeric LPS and this interaction occurs even better in the absence of LBP $[106,168]$. Taking these data into consideration, we concluded that CD11b/CD18 is not an appropriate target for "antibody"-based therapy even when anti-CD11b Fab/F(ab' )$_{2}$ fragments are used.

\section{Conclusions}

In summary, several conclusions can be drawn. Neither mIgG2a nor mIgG1 are able to stimulate $\mathrm{Ca}^{2+}$ mobilization and ROS production in freshly isolated PMNs.

Sufficient signals for phosphoinositide breakdown could be induced in monocytes by CD14 association with CD64. Moreover, this heterotypic CD14 association with CD64/CD32 (anti-CD14 ${ }^{\text {UCHM-1 }} \mathrm{Fc}^{\text {mIgG2a }}$ ) or association of two CD32 receptors together $\left(\mathrm{CD} 32 \leftarrow\right.$ anti-CD $32{ }^{\mathrm{CIKM} 5} \mathrm{Fc}$ mIgG1 $\rightarrow$ CD32) leads to $\mathrm{Ca}^{2+}$ signaling in monocytes. The homotypic CD32 association is less effective in $\mathrm{Ca}^{2+}$ signaling than heterotypic association of CD14 with CD64. In spite of this, CD14 association with CD64 is not enough to trigger $\mathrm{O}_{2}$. ${ }^{-} /$ROS production in monocytes. $\mathrm{Ca}^{2+}$ signaling caused by CD64/CD32 engagement without crosslinking is weaker than that induced by fMLP.

In monocytes not only sufficient production of $\mathrm{PI}(4,5) \mathrm{P}_{2}$ but also robust upregulation of intracellular $\mathrm{H}_{2} \mathrm{O}_{2} / \mathrm{ROS}$ is initiated in response to broad CD14 crosslinking by anti$\mathrm{CD} 14^{\mathrm{mIgG1}}$ antibodies and secondary $\mathrm{F}\left(\mathrm{ab}^{\prime}\right)_{2}$. In PMNs, this effect of CD14 crosslinking is less pronounced. TLR4 crosslinking [anti-TLR4 ${ }^{76 \mathrm{~B} 351.1} \mathrm{Fc}^{\mathrm{mIgG} 2 \mathrm{~b}}$ plus $\mathrm{F}\left(\mathrm{ab}^{\prime}\right)_{2}$ ] does not have the same effect on $\mathrm{PI}(4,5) \mathrm{P}_{2}$ production as CD14 crosslinking. Thus, $\mathrm{PI}(4,5) \mathrm{P}_{2}$ generation is a specific response to CD14 crosslinking (clustering).

Antigenic recognition of $\mathrm{CD} 32$ by anti-CD $32^{\text {IV.3/AT-10 }}$ $\mathrm{Fab} / \mathrm{F}\left(\mathrm{ab}^{\prime}\right)_{2}$ is already able to induce ITAMi signaling in PMNs thereby suppressing both constitutive and fMLPtriggered $\mathrm{O}_{2}{ }^{--} / \mathrm{ROS}$ production. Antigenic recognition of CD16 by anti-CD $16^{3 \mathrm{G} 8} \mathrm{Fab} / \mathrm{F}\left(\mathrm{ab}^{\prime}\right)_{2}$ is unable to prime or activate PMNs for intracellular $\mathrm{O}_{2}{ }^{--} / \mathrm{ROS}$ production.

In most cases in PMNs, targeting CD11b $\left[\mathrm{Fab}^{44}\right]$ causes "outside-in" signaling and generation of intracellular $\mathrm{H}_{2} \mathrm{O}_{2} / \mathrm{ROS}\left[\mathrm{Fab} / \mathrm{F}\left(\mathrm{ab}^{\prime}\right)_{2}{ }^{\mathrm{OKM} 1}\right]$. Antigenic recognition of both $\mathrm{CD} 11 \mathrm{~b} / \mathrm{CD} 18$ subunits by $\mathrm{F}\left(\mathrm{ab}^{\prime}\right)_{2}{ }^{\mathrm{IB} 4}$ stimulates $\mathrm{Ca}^{2+}$ mobilization in the similar extent as the whole IB4 antibody. In PMNs, antibody-dependent [anti-CD11b ${ }^{\text {mIgG1/mIgG2a }}$ association of CD11b/CD18 with CD32 or CD64 without crosslinking (clustering) does not induce sufficient $\mathrm{Ca}^{2+}$ mobilization and intracellular $\mathrm{O}_{2}{ }^{--}$/ ROS production. Thus, 
nonagonistic targeting CD11b followed by its association with CD32 is not enough to activate PMNs for significant $\mathrm{H}_{2} \mathrm{O}_{2}$ /ROS generation but it takes place when CD11b will be targeted by agonistic antibody followed by CD32 engagement. A high sensitivity of CD11b/CD18 to environmental stimuli including antibodies and its ability to initiate “inside-out" signaling makes CD11b/CD18 not an appropriate target for "antibody"-based therapy even if anti-CD11b $\mathrm{Fab} / \mathrm{F}\left(\mathrm{ab}^{\prime}\right)_{2}$ fragments would be used.

By contrast to CD11b/CD18, targeting CD14 by Fab or $\mathrm{F}\left(\mathrm{ab}^{\prime}\right)_{2}$ fragments is the most appropriate and safe approach for "antibody"-based therapy for LPS-induced deleterious effects even when innate immune cells are primed by PAMPs or endogenous priming molecules. A similar conclusion can be made accordingly targeting TLR 4 by specific $\mathrm{Fab} / \mathrm{F}\left(\mathrm{ab}^{\prime}\right)_{2}$ fragments. The effectiveness of anti-TLR4 Fab/F( $\left(\mathrm{bb}^{\prime}\right)_{2}$ fragments further may be potentiated by simultaneous use with anti-CD14 Fab/F(ab') $)_{2}$. However, it is necessary to kept in mind that partial TLR4 blockage may cause the better therapeutic effect since certain TLR4 activation is required for development of the adaptive immune responses. Anti-TLR4 antibody is able to interfere with TLR4 binding to LPS.MD-2 thereby preventing TLR4 dimerization in addition to engagement of CD32 and CD64 signaling pathways.

In light of the data presented and based on our own observations $[12,13,14]$, we can conclude that only anti$\mathrm{CD} 14^{\mathrm{UCHM}-1} \mathrm{Fc}^{\text {mIgG2a }}$ but neither anti-TLR $4^{\mathrm{HTA} 125} \mathrm{Fc}{ }^{\mathrm{mIgG2a}}$ nor anti-CD $11 \mathrm{~b}^{\mathrm{ICRF} 44} \mathrm{Fc}^{\mathrm{mIgG1}}$ antibodies are able to prevent significantly LPS-induced PMN priming for AMLP-triggered $\mathrm{O}_{2}^{--}$/ROS generation. Therefore, we confirm that CD14 is really the main TLR4 gatekeeper. We believe that anti$\mathrm{CD} 14 \mathrm{Fab} / \mathrm{F}\left(\mathrm{ab}^{\prime}\right)_{2}$ fragments will be very suitable for clinical use and could improve outcomes during LPS-initiated inflammation.

\section{Abbreviations}

$\begin{array}{ll}\text { ADP: } & \text { Adenosine diphosphate } \\ \text { ARF6: } & \text { ADP-ribosylation factor 6 } \\ \text { CD14: } & \text { Glycosylphosphatidylinositol-anchored } \\ & \text { protein } \\ \text { DAG: } & \text { Diacylglycerol } \\ \text { DAMPs: } & \text { Damage-associated molecular patterns } \\ \text { ERK: } & \text { Extracellularly regulated kinase } \\ \text { Fc } \gamma \text { Rs: } & \text { Fc receptors } \gamma \\ \text { FPR1: } & \text { Formyl peptide receptor 1 } \\ \text { fMLP: } & \text { N-Formyl-methionyl-leucyl- } \\ & \text { phenylalanine } \\ \text { GPCRs: } & \text { G protein-coupled receptors } \\ \text { GPI: } & \text { Glycosylphosphatidylinositol } \\ \text { GTPase: } & \text { Guanine nucleotide triphosphatase } \\ \text { IC: } & \text { Immune complexes } \\ \text { IL: } & \text { Interleukin } \\ \text { INF- } \gamma, \beta: & \text { Interferon } \gamma, \beta \\ \text { Ins }(1,4,5) P_{3}: & \text { Inositol 1,4,5-triphosphate } \\ \text { IRAK: } & \text { IL-1 receptor-associated kinase } \\ \text { IRF3: } & \text { Interferon regulatory factor 3 }\end{array}$

ITAM: Immunoreceptor tyrosine-based activation motif

ITIM: $\quad$ Immunoreceptor tyrosine-based inhibitory motif

LBP: $\quad$ Lipopolysaccharide-binding protein

LPS: $\quad$ Lipopolysaccharide (endotoxin)

LRR: $\quad$ Leucine rich repeat

MAPK: Mitogen-activated protein kinase

MCP-1: $\quad$ Monocyte chemoattractant protein 1

MD-2: $\quad$ Myeloid differentiation factor 2

MEK: $\quad$ Mitogen-activated ERK-activated kinase (also referred as MAP2K, MAPKK)

MIP-3 $\alpha$ : Macrophage inflammatory protein $3 \alpha$

MKK3: $\quad$ Mitogen-activated protein kinase kinase 3 (also referred as MAP2K3, MAPKK3, MEK3, and SAPKK-2)

MyD88: $\quad$ Myeloid factor of differentiation 88

NADPH oxidase: Nicotinamide adenine dinucleotide phosphate oxidase

NF- $\kappa$ B: $\quad$ Nuclear factor $\kappa$-light-chain-enhancer of activated B cells

NOX4: $\quad$ NADPH oxidase complex 4

PAMPs: $\quad$ Pathogen-associated molecular patterns

PBMC: $\quad$ Peripheral blood mononuclear cells

PI3K: $\quad$ Phosphatidylinositol 3-kinase

PIP5K: $\quad$ Phosphatidylinositol 4-phosphate 5-

PLC: $\quad$ Phospholipase C

PLD: $\quad$ Phospholipase D

$\operatorname{PtdIns}(3,4,5) \mathrm{P}_{3}$ or $\mathrm{PI}(3,4,5) \mathrm{P}_{3}$ :

PtdIns $(4,5) \mathrm{P}_{2}$ or $\mathrm{PI}(4,5) \mathrm{P}_{2}$ :

PTK:

PMNs:

$\mathrm{PKB} /$ Akt:

Raf:

ROS:

SHP-1:

SOD:

TAK1:

TGF- $\beta$ :

TNF- $\alpha$ :

TICAM-1:

TIR:

TIRAP/MAL: TIR domain-containing adaptor protein

TLR:

TRAF6:

TRAM:

TRIF:

Vav-1/RacGEF:

VD3:

DHR:

DCFDA:

O-4' MPLA:
Phosphatidylinositol 3,4,5-triphosphate

Phosphatidylinositol 4,5-bis-phosphate

Protein tyrosine kinase

Polymorphonuclear leukocytes

Protein kinase B or serine/threonine-specific protein kinase alpha

Serine/threonine-protein kinase

Reactive oxygen species

Protein tyrosine phosphatase 1

Superoxide dismutase

TGF- $\beta$-activated kinase

Transforming growth factor $\beta$

Tumor necrosis factor $\alpha$

TIR domain-containing adaptor molecule 1

Toll/interleukin-1 receptor domain

also known as MyD88 adaptor-like

Toll-like receptor

TNF- $\alpha$ receptor-associated factor

TRIF-related adaptor molecule

TIR domain-containing adaptor inducing interferon-beta

Guanine nucleotide exchange factor

$1 \alpha, 25$-Dihydroxyvitamin D3

Dihydrorhodamine 123

$2^{\prime}, 7^{\prime}$-Dichlorofluorescein diacetate

O-4' monophosphorylated lipid A. 


\section{Conflicts of Interest}

The authors declare no conflict of interest.

\section{Acknowledgments}

This study was financially supported by the Mission of the National Government NAAA-A17-117030110138-2 established by the Ministry of Education and Science of the Russian Federation (Minobrnauka).

\section{References}

[1] H. Tsukamoto, K. Fukudome, S. Takao et al., "Multiple potential regulatory sites of TLR4 activation induced by LPS as revealed by novel inhibitory human TLR4 mAbs," International Immunology, vol. 24, no. 8, pp. 495-506, 2012.

[2] W. Gao, Y. Xiong, Q. Li, and H. Yang, "Inhibition of TollLike Receptor Signaling as a Promising Therapy for Inflammatory Diseases: A Journey from Molecular to Nano Therapeutics," Frontiers in Physiology, vol. 8, 2017.

[3] N. Kuzmich, K. Sivak, V. Chubarev, Y. Porozov, T. SavateevaLyubimova, and F. Peri, "TLR4 Signaling Pathway Modulators as Potential Therapeutics in Inflammation and Sepsis," Vaccines, vol. 5, no. 4, p. 34, 2017.

[4] Q. u. Ain, M. Batool, and S. Choi, "TLR4-Targeting Therapeutics: Structural Basis and Computer-Aided Drug Discovery Approaches," Molecules, vol. 25, no. 3, p. 627, 2020.

[5] H. Tsukamoto, I. Ukai, Y. Yamagata et al., "Leucine-rich repeat 2 of human Toll-like receptor 4 contains the binding site for inhibitory monoclonal antibodies," Federation of European Biochemical Societies Letters, vol. 589, no. 24PartB, pp. 3893-3898, 2015.

[6] H. Tsukamoto, Y. Yamagata, I. Ukai et al., "An inhibitory epitope of human Toll-like receptor 4 resides on leucine-rich repeat 13 and is recognized by a monoclonal antibody," Federation of European Biochemical Societies Letters, vol. 591, no. 16, pp. 2406-2416, 2017.

[7] E. Monnet, G. Lapeyre, E. V. Poelgeest et al., "Evidence of NI0101 pharmacological activity, an anti-TLR4 antibody, in a randomized phase I dose escalation study in healthy volunteers receiving LPS," Clinical Pharmacology \& Therapeutics, vol. 101, no. 2, pp. 200-208, 2017.

[8] D. Wolf, N. Anto-Michel, H. Blankenbach et al., "A ligandspecific blockade of the integrin Mac-1 selectively targets pathologic inflammation while maintaining protective hostdefense," Nature Communications, vol. 9, no. 1, p. 525, 2018.

[9] E. Monnet, E. H. Choy, I. McInnes et al., "Efficacy and safety of NI-0101, an anti-toll-like receptor 4 monoclonal antibody, in patients with rheumatoid arthritis after inadequate response to methotrexate: a phase II study," Annals of the Rheumatic Diseases, vol. 79, no. 3, pp. 316-323, 2020.

[10] C. A. Spek, A. Verbon, H. Aberson et al., "Treatment with an anti-CD14 monoclonal antibody delays and inhibits lipopolysaccharide-induced gene expression in humans in vivo," Journal of Clinical Immunology, vol. 23, no. 2, pp. 132-140, 2003.

[11] I. Dunn-Siegrist, O. Leger, B. Daubeuf et al., "Pivotal involvement of Fc $\gamma$ receptor IIA in the neutralization of lipopolysaccharide signaling via a potent novel anti-TLR4 monoclonal antibody 15C1," Journal of Biological Chemistry, vol. 282, no. 48, pp. 34817-34827, 2007.
[12] D. S. Kabanov and I. R. Prokhorenko, "Involvement of Tolllike receptor 4 and $\mathrm{Fc}$ receptors gamma in human neutrophil priming by endotoxins from Escherichia coli," Biochemistry, vol. 78, no. 2, pp. 185-193, 2013.

[13] D. S. Kabanov, S. V. Grachev, and I. R. Prokhorenko, "Role of CD11b/CD18 in priming of human leukocytes by endotoxin glycoforms from Escherichia coli," Biochemistry, vol. 79, no. 8, pp. 812-819, 2014.

[14] D. S. Kabanov, O. Y. Vwedenskaya, M. A. Fokina, E. M. Morozova, S. V. Grachev, and I. R. Prokhorenko, "Impact of CD14 on reactive oxygen species production from human leukocytes primed byEscherichia coliLipopolysaccharides," Oxidative Medicine and Cellular Longevity, vol. 2019, Article ID 6043245, 9 pages, 2019.

[15] D. S. Kabanov, D. A. Serov, S. V. Zubova, S. V. Grachev, and I. R. Prokhorenko, "Dynamics of antagonistic potency of Rhodobacter capsulatus PG lipopolysaccharide against endotoxin-induced effects," Biochemistry, vol. 81, no. 3, pp. 275-283, 2016.

[16] D. S. Kabanov, V. A. Rykov, S. V. Prokhorenko, A. N. Murashev, and I. R. Prokhorenko, "In vivo proinflammatory cytokine production by $\mathrm{CD}-1$ mice in response to equipotential doses of Rhodobacter capsulatus PG and Salmonella enterica lipopolysaccharides," Biochemistry, vol. 83, no. 7, pp. 846-854, 2018.

[17] S. Jin, F. Zhou, F. Katirai, and P.-L. Li, "Lipid raft redox signaling: molecular mechanisms in health and disease," Antioxidants \& Redox Signaling, vol. 15, no. 4, pp. 1043-1083, 2011.

[18] S. J. Forrester, D. S. Kikuchi, M. S. Hernandes, Q. Xu, and K. K. Griendling, "Reactive oxygen species in metabolic and inflammatory signaling," Circulation Research, vol. 122, no. 6, pp. 877-902, 2018.

[19] J. Zhang, X. Wang, V. Vikash et al., "ROS and ROS-mediated cellular signaling," Oxidative Medicine and Cellular Longevity, vol. 2016, Article ID 4350965, 18 pages, 2016.

[20] N. Di Marzo, E. Chisci, and R. Giovannoni, "The role of Hydrogen peroxide in redox-dependent signaling: homeostatic and pathological responses in mammalian cells," Cells, vol. 7, no. 10, p. 156, 2018.

[21] A. Ngkelo, K. Meja, M. Yeadon, I. Adcock, and P. A. Kirkham, "LPS induced inflammatory responses in human peripheral blood mononuclear cells is mediated through NOX4 and Gi-alpha dependent PI-3kinase signalling," Journal of Inflammation, vol. 9, no. 1, p. 1, 2012.

[22] H. S. Park, H. Y. Jung, E. Y. Park, J. Kim, W. J. Lee, and Y. S. Bae, "Cutting edge: direct interaction of TLR4 with $\mathrm{NAD}(\mathrm{P}) \mathrm{H}$ oxidase 4 isozyme is essential for lipopolysaccharide-induced production of reactive oxygen species and activation of NF- $\kappa \mathrm{B}$," The Journal of Immunology, vol. 173, no. 6, pp. 3589-3593, 2004.

[23] M. G. Netea, L. A. B. Joosten, E. Latz et al., "Trained immunity: a program of innate immune memory in health and disease," Science, vol. 352, no. 6284, p. aaf1098, 2016.

[24] C. Rosales, "Neutrophil: A Cell with Many Roles in Inflammation or Several Cell Types?," Frontiers in Physiology, vol. 9, 2018.

[25] P. A. Kramer, S. Ravi, B. Chacko, M. S. Johnson, and V. M. Darley-Usmar, "A review of the mitochondrial and glycolytic metabolism in human platelets and leukocytes: implications for their use as bioenergetic biomarkers," Redox Biology, vol. 2, pp. 206-210, 2014. 
[26] H.-Y. Tan, N. Wang, S. Li, M. Hong, X. Wang, and Y. Feng, "The reactive oxygen species in macrophage polarization: reflecting its dual role in progression and treatment of human diseases," Oxidative Medicine and Cellular Longevity, vol. 2016, Article ID 2795090, 16 pages, 2016.

[27] B. Fuhrman, M. Shiner, N. Volkova, and M. Aviram, "Cellinduced copper ion-mediated low density lipoprotein oxidation increases during in vivo monocyte-to-macrophage differentiation," Free Radical Biology and Medicine, vol. 37, no. 2, pp. 259-271, 2004.

[28] A. C. Bulua, A. Simon, R. Maddipati et al., "Mitochondrial reactive oxygen species promote production of proinflammatory cytokines and are elevated in TNFR1-associated periodic syndrome (TRAPS)," Journal of Experimental Medicine, vol. 208, no. 3, pp. 519-533, 2011.

[29] M. G. Netea, A. Simon, F. van de Veerdonk, B.-J. Kullberg, J. W. M. Van der Meer, and L. A. B. Joosten, "IL-1 $\beta$ Processing in Host Defense: Beyond the Inflammasomes," PLoS Pathogens, vol. 6, no. 2, p. e1000661, 2010.

[30] M. Reiss and D. Roos, "Differences in Oxygen metabolism of phagocytosing monocytes and neutrophils," The Journal of Clinical Investigation, vol. 61, no. 2, pp. 480-488, 1978.

[31] G. Fossati, D. A. Moulding, D. G. Spiller, R. J. Moots, M. R. H. White, and S. W. Edwards, "The mitochondrial network of human neutrophils: role in chemotaxis, phagocytosis, respiratory burst activation, and commitment to apoptosis," The Journal of Immunology, vol. 170, no. 4, pp. 1964-1972, 2003.

[32] G. T. Nguyen, E. R. Green, and J. Mecsas, "Neutrophils to the ROScue: mechanisms of NADPH oxidase activation and bacterial resistance," Frontiers in Cellular and Infection Microbiology, vol. 7, 2017.

[33] J. El-Benna, P. M.-C. Dang, and M.-A. Gougerot-Pocidalo, "Priming of the neutrophil NADPH oxidase activation: role of $\mathrm{p} 47^{\text {phox }}$ phosphorylation and NOX2 mobilization to the plasma membrane," Seminars in Immunopathology, vol. 30, no. 3, pp. 279-289, 2008.

[34] J. G. Moreland, A. P. Davis, J. J. Matsuda et al., "Endotoxin priming of neutrophils requires NADPH oxidase-generated oxidants and is regulated by the anion transporter $\mathrm{ClC}-3$," The Journal of Biological Chemistry, vol. 282, no. 47, pp. 33958-33967, 2007.

[35] S. Bréchard, S. Plançon, and E. J. Tschirhart, "New Insights into the Regulation of Neutrophil NADPH Oxidase Activity in the Phagosome: A Focus on the Role of Lipid and Ca2+Signaling," Antioxidants \& Redox Signaling, vol. 18, no. 6, pp. 661-676, 2013.

[36] Y. Mazaki, S. Hashimoto, T. Tsujimura et al., "Neutrophil direction sensing and superoxide production linked by the GTPase-activating protein GIT2," Nature Immunology, vol. 7, no. 7, pp. 724-731, 2006.

[37] J. Schymeinsky, A. Mócsai, and B. Walzog, "Neutrophil activation via $\beta 2$ integrins (CD11/CD18): Molecular mechanisms and clinical implications," Thrombosis and Haemostasis, vol. 98, no. 8, pp. 262-273, 2017.

[38] I. Miralda, S. M. Uriarte, and K. R. McLeish, "Multiple Phenotypic Changes Define Neutrophil Priming," Frontiers in Cellular and Infection Microbiology, vol. 7, 2017.

[39] F. R. DeLeo, J. Renee, S. McCormick et al., "Neutrophils exposed to bacterial lipopolysaccharide upregulate NADPH oxidase assembly," The Journal of Clinical Investigation, vol. 101, no. 2, pp. 455-463, 1998.
[40] L. R. Prince, M. K. Whyte, I. Sabroe, and L. C. Parker, "The role of TLRs in neutrophil activation," Current Opinion in Pharmacology, vol. 11, no. 4, pp. 397-403, 2011.

[41] A. Pfeiffer, A. Böttcher, E. Orsó et al., "Lipopolysaccharide and ceramide docking to CD14 provokes ligand-specific receptor clustering in rafts," European Journal of Immunology, vol. 31, no. 11, pp. 3153-3164, 2001.

[42] G. Schmitz and E. Orsó, "CD14 signalling in lipid rafts: new ligands and co-receptors," Current Opinion in Lipidology, vol. 13, no. 5, pp. 513-521, 2002.

[43] D. S. Kabanov, Y. V. Radzyukevich, S. V. Grachev, and I. R. Prokhorenko, “Влияние структуры липида А липополисахаридов на их взаимодействие с ЛПС-связывающим белком сыворотки крови и активацию лейкоцитов," Biological Membranes (Moscow), vol. 35, no. 5, pp. 341-350, 2018.

[44] A. Pfeiffer, M. Kapinsky, E. Orsó et al., "The Cholesterol Content of the Plasma Membrane as a Regulator of CD14 Dependent Signal Transduction," Single Molecules, vol. 2, no. 2, pp. 113-115, 2001.

[45] K. Miyake, "Innate recognition of lipopolysaccharide by Tolllike receptor 4-MD-2," Trends in Microbiology, vol. 12, no. 4, pp. 186-192, 2004.

[46] H. Oshiumi, M. Sasai, K. Shida, T. Fujita, M. Matsumoto, and T. Seya, "TIR-containing adapter molecule (TICAM)-2, a bridging adapter recruiting to toll-like receptor 4 TICAM-1 that induces interferon-beta," Journal of Biological Chemistry, vol. 278, no. 50, pp. 49751-49762, 2003.

[47] T. Horng, G. M. Barton, and R. Medzhitov, "TIRAP: an adapter molecule in the Toll signaling pathway," Nature Immunology, vol. 2, no. 9, pp. 835-841, 2001.

[48] M. Yamamoto, "Role of adaptor TRIF in the MyD88independent toll-like receptor signaling pathway," Science, vol. 301, no. 5633, pp. 640-643, 2003.

[49] M. Yamamoto, S. Sato, H. Hemmi et al., "TRAM is specifically involved in the Toll-like receptor 4-mediated MyD88independent signaling pathway," Nature Immunology, vol. 4, no. 11, pp. 1144-1150, 2003.

[50] T. Kawai, O. Takeuchi, T. Fujita et al., "Lipopolysaccharide stimulates the MyD88-independent pathway and results in activation of IFN-regulatory factor 3 and the expression of a subset of lipopolysaccharide-inducible genes," The Journal of Immunology, vol. 167, no. 10, pp. 5887-5894, 2001.

[51] S. M. Zughaier, S. M. Zimmer, A. Datta, R. W. Carlson, and D. S. Stephens, "Differential induction of the Toll-like receptor 4-MyD88-dependent and -independent signaling pathways by Endotoxins," Infection and Immunity, vol. 73, no. 5, pp. 2940-2950, 2005.

[52] N. Tamassia, V. Le Moigne, F. Calzetti et al., "The MyD88independent pathway is not mobilized in human neutrophils stimulated via TLR4," Journal of Immunology, vol. 178, no. 11, pp. 7344-7356, 2007.

[53] J. A. Nick, N. J. Avdi, S. K. Young et al., "Selective activation and functional significance of p38 $\alpha$ mitogen-activated protein kinase in lipopolysaccharide-stimulated neutrophils," Journal of Clinical Investigation, vol. 103, no. 6, pp. 851858, 1999.

[54] J. El-Benna, M. Hurtado-Nedelec, V. Marzaioli, J.-C. Marie, M.-A. Gougerot-Pocidalo, and P. M.-C. Dang, "Priming of the neutrophil respiratory burst: role in host defense and 
inflammation," Immunological Reviews, vol. 273, no. 1, pp. 180-193, 2016.

[55] K. Futosi, S. Fodor, and A. Mócsai, "Neutrophil cell surface receptors and their intracellular signal transduction pathways," International Immunopharmacology, vol. 17, no. 3, pp. 638-650, 2013.

[56] J. B. Klein, A. Buridi, P. Y. Coxon et al., "Role of extracellular signal-regulated kinase and phosphatidylinositol-3 kinase in chemoattractant and LPS delay of constitutive neutrophil apoptosis," Cellular Signalling, vol. 13, no. 5, pp. 335-343, 2001.

[57] D. D. Browning, N. D. Windes, and R. D. Ye, “Activation of p38 mitogen-activated protein kinase by lipopolysaccharide in human neutrophils requires nitric oxide-dependent cGMP accumulation," The Journal of Biological Chemistry, vol. 274, no. 1, pp. 537-542, 1999.

[58] A. M. Condliffe, E. Kitchen, and E. R. Chilvers, "Neutrophil priming: pathophysiological consequences and underlying mechanisms," Clinical Science, vol. 94, no. 5, pp. 461-471, 1998.

[59] P. Chames, M. Van Regenmortel, E. Weiss, and D. Baty, "Therapeutic antibodies: successes, limitations and hopes for the future," British Journal of Pharmacology, vol. 157, no. 2, pp. 220-233, 2009.

[60] F. Nimmerjahn and J. V. Ravetch, "Antibodies, Fc receptors and cancer," Current Opinion in Immunology, vol. 19, no. 2, pp. 239-245, 2007.

[61] L. Shang, B. Daubeuf, M. Triantafilou et al., "Selective antibody intervention of Toll-like receptor 4 activation through Fc $\gamma$ receptor tethering," The Journal of Biological Chemistry, vol. 289, no. 22, pp. 15309-15318, 2014.

[62] R. Wang, J. Stephens, and M. J. Lacy, "Characterization of monoclonal antibody HTA125 with specificity for human TLR4," Hybridoma and Hybridomics, vol. 22, no. 6, pp. 357-365, 2003.

[63] S. J. Gadd, R. Eher, O. Majdic, and W. Knapp, "Signal transduction via Fc gamma $\mathrm{R}$ and Mac-1 alpha-chain in monocytes and polymorphonuclear leucocytes," The Journal of Immunology, vol. 81, no. 4, pp. 611-617, 1994.

[64] E. A. Macintyre, P. J. Roberts, M. Jones et al., "Activation of human monocytes occurs on cross-linking monocytic antigens to an Fc receptor," The Journal of Immunology, vol. 142, no. 7, pp. 2377-2383, 1989.

[65] E. van Mirre, W. B. Breunis, J. Geissler et al., "Neutrophil responsiveness to IgG, as determined by fixed ratios of mRNA levels for activating and inhibitory Fc $\gamma$ RII (CD32), is stable over time and unaffected by cytokines," Blood, vol. 108, no. 2, pp. 584-590, 2006.

[66] S. Rivas-Fuentes, E. Garcia-Garcia, G. Nieto-Castaneda, and C. Rosales, "Fc $\gamma$ receptors exhibit different phagocytosis potential in human neutrophils," Cellular Immunology, vol. 263, no. 1, pp. 114-121, 2010.

[67] J. G. J. van de Winkel and C. L. Anderson, "Biology of human immunoglobulin G Fc receptors," Journal of Leukocyte Biology, vol. 49, no. 5, pp. 511-524, 1991.

[68] J. G. J. van de Winkel and P. J. A. Capel, "Human IgG Fc receptor heterogeneity: molecular aspects and clinical implications," Immunology Today, vol. 14, no. 5, pp. 215-221, 1993.

[69] P. M. Guyre, R. F. Graziano, B. A. Vance, P. M. Morganelli, and M. W. Fanger, "Monoclonal antibodies that bind to dis- tinct epitopes on Fc gamma RI are able to trigger receptor function," The Journal of Immunology, vol. 143, no. 5, pp. 1650-1655, 1989.

[70] B. Walzog, R. Seifert, A. Zakrzewicz, P. Gaehtgens, and K. Ley, "Cross-linking of CD18 in human neutrophils induces an increase of intracellular free $\mathrm{Ca}^{2+}$, exocytosis of azurophilic granules, quantitative up-regulation of CD18, shedding of L-selectin, and actin polymerization," Journal of Leukocyte Biology, vol. 56, no. 5, pp. 625-635, 1994.

[71] T. W. Huizinga, F. van Kemenade, L. Koenderman et al., "The $40-\mathrm{kDa}$ Fc gamma receptor (FcRII) on human neutrophils is essential for the IgG-induced respiratory burst and IgG-induced phagocytosis," The Journal of Immunology, vol. 142, no. 7, pp. 2365-2369, 1989.

[72] J. C. Edberg and R. P. Kimberly, "Modulation of Fc gamma and complement receptor function by the glycosylphosphatidylinositol-anchored form of Fc gamma RIII," The Journal of Immunology, vol. 152, no. 12, pp. 5826-5835, 1994.

[73] A. Ortiz-Stern and C. Rosales, "Cross-talk between Fc receptors and integrins," Immunology Letters, vol. 90, no. 2-3, pp. 137-143, 2003.

[74] T. K. Means and A. D. Luster, "Integrins limit the Toll," Nature Immunology, vol. 11, no. 8, pp. 691-693, 2010.

[75] A. J. Melendez, L. Bruetschy, R. A. Floto, M. M. Harnett, and J. M. Allen, "Functional coupling of Fc $\gamma$ RI to nicotinamide adenine dinucleotide phosphate (reduced form) oxidative burst and immune complex trafficking requires the activation of phospholipase D1," Blood, vol. 98, no. 12, pp. 3421-3428, 2001.

[76] A. P. Ociennikowska, M. I. Zdioruk, G. Traczyk, A. Swiatkowska, and K. Kwiatkowska, "LPS-induced clustering of CD14 triggers generation of $\mathrm{PI}(4,5) \mathrm{P}_{2}$," Journal of Cell Science, vol. 128, no. 22, pp. 4096-4111, 2015.

[77] S. R. Yan, W. Al-Hertani, D. Byers, and R. Bortolussi, "Lipopolysaccharide-binding protein- and CD14-dependent activation of mitogen-activated protein kinase p38 by lipopolysaccharide in human neutrophils is associated with priming of respiratory burst," Infection and Immunity, vol. 70, no. 8, pp. 4068-4074, 2002.

[78] E. A. MacIntyre, P. J. Roberts, R. Abdul-Gaffar et al., "Mechanism of human monocyte activation via the $40-\mathrm{kDa} \mathrm{Fc}$ receptor for IgG," The Journal of Immunology, vol. 141, no. 12 , pp. 4333-4343, 1988.

[79] A. Plociennikowska, A. Hromada-Judycka, K. Borzecka, and K. Kwiatkowska, "Co-operation of TLR4 and raft proteins in LPS-induced pro-inflammatory signaling," Cellular and Molecular Life Sciences, vol. 72, no. 3, pp. 557-581, 2015.

[80] J. Pugin, V. V. Kravchenko, J.-D. Lee, L. Kline, R. J. Ulevitch, and P. S. Tobias, "Cell activation mediated by glycosylphosphatidylinositol-anchored or transmembrane forms of CD14," Infection and Immunity, vol. 66, no. 3, pp. 1174-1180, 1998.

[81] F. Lund-Johansen, J. Olweus, A. Aarli, and R. Bjerknes, "Signal transduction in human monocytes and granulocytes through the PI-linked antigen CD14," FEBS Letters, vol. 273, no. 1-2, pp. 55-58, 1990.

[82] Z. Wu, Z. Zhang, Z. Lei, and P. Lei, "CD14: biology and role in the pathogenesis of disease," Cytokine and Growth Factor Reviews, vol. 48, pp. 24-31, 2019.

[83] F. Lund-Johansen, J. Olweus, F. W. Symington et al., "Activation of human monocytes and granulocytes by monoclonal 
antibodies to glycosylphosphatidylinositol-anchored antigens," European Journal of Immunology, vol. 23, no. 11, pp. 2782-2791, 1993.

[84] P. Antal-Szalmas, J. A. G. van Strijp, A. J. L. Weersink et al., "Quantitation of surface CD14 on human monocytes and neutrophils," Journal of Leukocyte Biology, vol. 61, no. 6, pp. 721-728, 1997.

[85] I. Stefanova, M. L. Corcoran, E. M. Horak, L. M. Wahl, J. B. Bolen, and I. D. Horak, "Lipopolysaccharide induces activation of CD14-associated protein tyrosine kinase p53/56lyn," The Journal of Biological Chemistry, vol. 268, no. 28, pp. 20725-20728, 1993.

[86] B. Seed, "Initiation of signal transduction by receptor aggregation: role of nonreceptor tyrosine kinases," Seminars in Immunology, vol. 7, no. 1, pp. 3-11, 1995.

[87] E. B. Lynam, S. I. Simon, Y. P. Rochon, and L. A. Sklar, "Lipopolysaccharide enhances CD11b/CD18 function but inhibits neutrophil aggregation," Blood, vol. 83, no. 11, pp. 33033311, 1994

[88] M. D. Cunningham, R. A. Shapiro, C. Seachord, K. Ratcliffe, L. Cassiano, and R. P. Darveau, "CD14 Employs Hydrophilic Regions to "Capture" Lipopolysaccharides," The Journal of Immunology, vol. 164, no. 6, pp. 3255-3263, 2000.

[89] J.-I. Kim, C. J. Lee, M. S. Jin et al., "Crystal structure of CD14 and its implications for lipopolysaccharide signaling," The Journal of Biological Chemistry, vol. 280, no. 12, pp. 1134711351, 2005.

[90] A. Troelstra, B. N. G. Giepmans, K. P. M. van Kessel, H. S. Lichenstein, J. Verhoef, and J. A. G. van Strijp, "Dual effects of soluble CD14 on LPS priming of neutrophils," Journal of Leukocyte Biology, vol. 61, no. 2, pp. 173-178, 1997.

[91] R. Landmann, F. Scherer, R. Schumann, S. Link, S. Sansano, and W. Zimmerli, "LPS directly induces oxygen radical production in human monocytes via LPS binding protein and CD14," Journal of Leukocyte Biology, vol. 57, no. 3, pp. 440449, 1995.

[92] R. Weingarten, L. A. Sklar, J. C. Mathison et al., "Interactions of lipopolysaccharide with neutrophils in blood via CD14," Journal of Leukocyte Biology, vol. 53, no. 5, pp. 518-524, 1993.

[93] W. A. Lynn, C. R. H. Raetz, N. Qureshi, and D. T. Golenbock, "Lipopolysaccharide-induced stimulation of CD11b/CD18 expression on neutrophils. Evidence of specific receptorbased response and inhibition by lipid A-based antagonists," The Journal of Immunology, vol. 147, no. 9, pp. 3072-3079, 1991.

[94] P. S. Tobias, K. Soldau, L. Kline et al., "Cross-linking of lipopolysaccharide (LPS) to CD14 on THP-1 cells mediated by LPS-binding protein," The Journal of Immunology, vol. 150, no. 7, pp. 3011-3021, 1993.

[95] R. Landmann, H.-P. Knopf, S. Link, S. Sansano, R. Schumann, and W. Zimmerli, "Human monocyte CD14 is upregulated by lipopolysaccharide," Infection and Immunity, vol. 64, no. 5, pp. 1762-1769, 1996.

[96] A. M. Soler-Rodriguez, H. Zhang, H. S. Lichenstein et al., "Neutrophil activation by bacterial lipoprotein versus lipopolysaccharide: differential requirements for serum and CD14," The Journal of Immunology, vol. 164, no. 5, pp. 2674-2683, 2000.

[97] F. Stelter, M. Bernheiden, R. Menzel et al., "Mutation of amino acids 39-44 of human CD14 Abrogates binding of lipopolysaccharide and Escherichia coli," European Journal of Biochemistry, vol. 243, no. 1-2, pp. 100-109, 1997.

[98] C. Hermann, I. Spreitzer, N. W. J. Schröder et al., "Cytokine induction by purified lipoteichoic acids from various bacterial species - role of LBP, sCD14, CD14 and failure to induce IL-12 and subsequent IFN- $\gamma$ release," European Journal of Immunology, vol. 32, no. 2, pp. 541-551, 2002.

[99] D. Heumann, P. Gallay, C. Barras et al., "Control of lipopolysaccharide (LPS) binding and LPS-induced tumor necrosis factor secretion in human peripheral blood monocytes," The Journal of Immunology, vol. 148, no. 11, pp. 3505-3512, 1992.

[100] K. Yasui, E. L. Becker, and R. I. Sha'afi, "Lipopolysaccharide and serum cause the translocation of G-protein to the membrane and prime neutrophils via CD14," Biochemical and Biophysical Research Communications, vol. 183, no. 3, pp. 1280-1286, 1992.

[101] P. Gallay, C. V. Jongeneel, C. Barras et al., "Short time exposure to lipopolysaccharide is sufficient to activate human monocytes," The Journal of Immunology, vol. 150, no. 11, pp. 5086-5093, 1993.

[102] M. Pollack, A. M. Espinoza, G. Guelde, N. L. Koles, L. M. Wahl, and C. A. Ohl, "Lipopolysaccharide (LPS)-specific monoclonal antibodies regulate LPS uptake and LPSinduced tumor necrosis Factor- Responses by human monocytes," The Journal of Infectious Diseases, vol. 172, no. 3, pp. 794-804, 1995.

[103] G. Qing, K. Rajaraman, and R. Bortolussi, "Diminished priming of neonatal polymorphonuclear leukocytes by lipopolysaccharide is associated with reduced CD14 expression," Infection and Immunity, vol. 63, no. 1, pp. 248-252, 1995.

[104] K. Yasui, A. Komiyama, T. F. Molski, and R. I. Sha'afi, "Pentoxifylline and CD14 antibody additively inhibit priming of polymorphonuclear leukocytes for enhanced release of superoxide by lipopolysaccharide: possible mechanism of these actions," Infection and Immunity, vol. 62, no. 3, pp. 922927, 1994.

[105] S. L. Weinstein, C. H. June, and A. L. DeFranco, "Lipopolysaccharide-induced protein tyrosine phosphorylation in human macrophages is mediated by CD14," The Journal of Immunology, vol. 151, no. 7, pp. 3829-3838, 1993.

[106] S. Noubir, Z. Hmama, and N. E. Reiner, "Dual receptors and distinct pathways mediate interleukin-1 receptor-associated kinase degradation in response to lipopolysaccharide. Involvement of CD14/TLR4, CR3, and phosphatidylinositol 3-kinase," The Journal of Biological Chemistry, vol. 279, no. 24, pp. 25189-25195, 2004.

[107] J. Pugin, D. Heumann, A. Tomasz et al., "CD14 is a pattern recognition receptor," Immunity, vol. 1, no. 6, pp. 509-516, 1994.

[108] R. I. Tapping, S. Akashi, K. Miyake, P. J. Godowski, and P. S. Tobias, "Toll-like receptor 4, but not Toll-like receptor 2, is a signaling receptor for Escherichia and Salmonella lipopolysaccharides," The Journal of Immunology, vol. 165, no. 10, pp. 5780-5787, 2000.

[109] D. J. Leturcq, A. M. Moriarty, G. Talbott, R. K. Winn, T. R. Martin, and R. J. Ulevitch, "Antibodies against CD14 protect primates from endotoxin-induced shock," The Journal of Clinical Investigation, vol. 98, no. 7, pp. 1533-1538, 1996.

[110] S. G. Elner, H. R. Petty, V. M. Elner et al., “TLR4 mediates human retinal pigment epithelial endotoxin binding and 
cytokine expression," Transactions of the American Ophthalmological Society, vol. 103, pp. 126-137, 2005.

[111] D. Iwaki, C. Nishitani, H. Mitsuzawa, N. Hyakushima, H. Sano, and Y. Kuroki, "The CD14 region spanning amino acids $57-64$ is critical for interaction with the extracellular Toll-like receptor 2 domain," Biochemical and Biophysical Research Communications, vol. 328, no. 1, pp. 173-176, 2005.

[112] S. Baveye, E. Elass, D. G. Fernig, C. Blanquart, J. Mazurier, and D. Legrand, "Human lactoferrin interacts with soluble CD14 and inhibits expression of endothelial adhesion molecules, E-selectin and ICAM-1, induced by the CD14lipopolysaccharide complex," Infection and Immunity, vol. 68 , no. 12 , pp. 6519-6525, 2000.

[113] D. Kim and J. Y. Kim, “Anti-CD14 antibody reduces LPS responsiveness via TLR4 internalization in human monocytes," Molecular Immunology, vol. 57, no. 2, pp. 210-215, 2014.

[114] T. Nakata, M. Yasuda, M. Fujita et al., "CD14 directly binds to triacylated lipopeptides and facilitates recognition of the lipopeptides by the receptor complex of Toll-like receptors 2 and 1 without binding to the complex," Cellular Microbiology, vol. 8, no. 12, pp. 1899-1909, 2006.

[115] M. Triantafilou, K. Triantafilou, and N. Fernandez, "Rough and smooth forms of fluorescein-labelled bacterial endotoxin exhibit CD14/LBP dependent and independent binding that is influencedby endotoxin concentration," European Journal of Biochemistry, vol. 267, no. 8, pp. 2218-2226, 2000.

[116] T. S.-C. Juan, E. Hailman, M. J. Kelley et al., "Identification of a lipopolysaccharide binding domain in CD14 between amino acids 57 and 64," The Journal of Biological Chemistry, vol. 270, no. 10, pp. 5219-5224, 1995.

[117] K. Kuronuma, H. Mitsuzawa, K. Takeda et al., “Anionic pulmonary surfactant phospholipids inhibit inflammatory responses from alveolar macrophages and U937 cells by binding the lipopolysaccharide-interacting proteins CD14 and MD-2," The Journal of Biological Chemistry, vol. 284, no. 38, pp. 25488-25500, 2009.

[118] M. A. Dentener, V. Bazil, E. J. U. von Asmuth, M. Ceska, and W. A. Buurman, "Involvement of CD14 in lipopolysaccharide-induced tumor necrosis factor-alpha, IL6 and IL-8 release by human monocytes and alveolar macrophages," The Journal of Immunology, vol. 150, no. 7, pp. 2885-2891, 1993.

[119] A. L. Blomkalns, L. L. Stoll, W. Shaheen et al., "Low level bacterial endotoxin activates two distinct signaling pathways in human peripheral blood mononuclear cells," Journal of Inflammation, vol. 8, no. 1, p. 4, 2011.

[120] A. Kato, T. Ogasawara, T. Homma, H. Saito, and K. Matsumoto, "Lipopolysaccharide-binding protein critically regulates lipopolysaccharide-induced IFN- $\beta$ signaling pathway in human monocytes," The Journal of Immunology, vol. 172, no. 10, pp. 6185-6194, 2004.

[121] M. Suzuki, C. Kato, and A. Kato, “Therapeutic antibodies: their mechanisms of action and the pathological findings they induce in toxicity studies," Journal of Toxicologic Pathology, vol. 28, no. 3, pp. 133-139, 2015.

[122] A. Verbon, P. E. P. Dekkers, T. ten Hove et al., "IC14, an antiCD14 antibody, inhibits endotoxin-mediated symptoms and inflammatory responses in humans," The Journal of Immunology, vol. 166, no. 5, pp. 3599-3605, 2001.

[123] L. A. J. O'Neill, C. E. Bryant, and S. L. Doyle, “Therapeutic targeting of Toll-like receptors for infectious and inflamma- tory diseases and cancer," Pharmacological Reviews, vol. 61, no. 2, pp. 177-197, 2009.

[124] S. Sugawara, S. Yang, K. Iki et al., "Monocytic cell activation by nonendotoxic glycoprotein from Prevotella intermedia ATCC 25611 is mediated by Toll-like receptor 2," Infection and Immunity, vol. 69, no. 8, pp. 4951-4957, 2001.

[125] S. M. Zughaier, Y.-L. Tzeng, S. M. Zimmer, A. Datta, R. W. Carlson, and D. S. Stephens, "Neisseria meningitidis lipooligosaccharide structure-dependent activation of the macrophage CD14/Toll-like receptor 4 pathway," Infection and Immunity, vol. 72, no. 1, pp. 371-380, 2004.

[126] C. Basak, S. K. Pathak, A. Bhattacharyya, D. Mandal, S. Pathak, and M. Kundu, "NF- $\kappa$ B- and C/EBP $\beta$-driven Interleukin- $\beta$ gene expression and PAK1-mediated caspase- 1 activation play essential roles in Interleukin- $1 \beta$ release fromHelicobacter pyloriLipopolysaccharidestimulated macrophages," The Journal of Biological Chemistry, vol. 280, no. 6, pp. 4279-4288, 2005.

[127] M. Martin, J. Katz, S. N. Vogel, and S. M. Michalek, "Differential induction of endotoxin tolerance by lipopolysaccharides derived from Porphyromonas gingivalis and Escherichia coli," The Journal of Immunology, vol. 167, no. 9, pp. 5278-5285, 2001.

[128] T. Ogawa, Y. Asai, Y. Sakai et al., "Endotoxic and immunobiological activities of a chemically synthesized lipid A of Helicobacter pylori strain 206-1," FEMS Immunology and Medical Microbiology, vol. 36, no. 1-2, pp. 1-7, 2003.

[129] V. Stadlbauer, R. P. Mookerjee, G. A. K. Wright et al., "Role of Toll-like receptors 2, 4, and 9 in mediating neutrophil dysfunction in alcoholic hepatitis," American Journal of Physiology Gastrointestinal and Liver Physiology, vol. 296, no. 1, pp. G15-G22, 2009.

[130] M. Martin, S. M. Michalek, and J. Katz, "Role of innate immune factors in the adjuvant activity of monophosphoryl lipid A," Infection and Immunity, vol. 71, no. 5, pp. 24982507, 2003.

[131] B. S. Park, D. H. Song, H. M. Kim, B.-S. Choi, H. Lee, and J.O. Lee, "The structural basis of lipopolysaccharide recognition by the TLR4-MD-2 complex," Nature, vol. 458, no. 7242, pp. 1191-1195, 2009.

[132] R. Shimazu, S. Akashi, H. Ogata et al., "MD-2, a molecule that confers lipopolysaccharide responsiveness on Toll-like receptor 4," Journal of Experimental Medicine, vol. 189, no. 11, pp. 1777-1782, 1999.

[133] T. Sanui, M. Takeshita, T. Fukuda, A. Haraguchi, Y. Aida, and F. Nishimura, "Anti-CD14 antibody-treated neutrophils respond to LPS: possible involvement of CD14 upregulated by anti-CD14 antibody binding," Immunological Investigations, vol. 46, no. 2, pp. 190-200, 2016.

[134] S. B. Mkaddem, G. Hayem, F. Jönsson et al., "Shifting Fc $\gamma$ RIIA-ITAM from activation to inhibitory configuration ameliorates arthritis," Journal of Clinical Investigation, vol. 124, no. 9, pp. 3945-3959, 2014.

[135] J. Loyau, G. Didelot, P. Malinge et al., "Robust antibodyantigen complexes prediction generated by combining sequence analyses, mutagenesis, in vitro evolution, X-ray crystallography and in silico docking," Journal of Molecular Biology, vol. 427, no. 16, pp. 2647-2662, 2015.

[136] K. Gomery, S. Muller-Loennies, C. L. Brooks et al., "Antibody WN1 222-5 mimics Toll-like receptor 4 binding in the recognition of LPS," in Proceedings of the National Academy of 
Sciences of the United States of America (PNAS), vol. 109no. 51, pp. 20877-20882, 2012.

[137] M.-J. Zhou and E. J. Brown, “CR3 (Mac-1, alpha M beta 2, $\mathrm{CD} 11 \mathrm{~b} / \mathrm{CD} 18)$ and Fc gamma RIII cooperate in generation of a neutrophil respiratory burst: requirement for $\mathrm{Fc}$ gamma RIII and tyrosine phosphorylation," The Journal of Cell Biology, vol. 125, no. 6, pp. 1407-1416, 1994.

[138] J. Greenman, A. L. Tutt, A. J. T. George, K. A. F. Pulford, G. T. Stevenson, and M. J. Glennie, "Characterization of a new monoclonal anti-Fc $\gamma$ RII antibody, AT10, and its incorporation into a bispecific $\mathrm{F}(\mathrm{ab})_{2}$ derivative for recruitment of cytotoxic effectors," Molecular Immunology, vol. 28, no. 11, pp. 1243-1254, 1991.

[139] S. Bournazos, S. P. Hart, L. H. Chamberlain, M. J. Glennie, and I. Dransfield, "Association of Fc $\gamma$ RIIA (CD32A) with lipid rafts regulates ligand binding Activity," The Journal of Immunology, vol. 182, no. 12, pp. 8026-8036, 2009.

[140] K. Su, H. Yang, X. Li et al., "Expression profile of Fc $\gamma$ RIIb on leukocytes and its dysregulation in systemic lupus erythematosus," The Journal of Immunology, vol. 178, no. 5, pp. 32723280, 2007.

[141] M.-J. Zhou, R. F. Todd III, J. G. J. van de Winkel, and H. R. Petty, "Cocapping of the leukoadhesin molecules complement receptor type 3 and lymphocyte function-associated antigen-1 with Fc gamma receptor III on human neutrophils. Possible role of lectin-like interactions," The Journal of Immunology, vol. 150, no. 7, pp. 3030-3041, 1993.

[142] P. Y. Coxon, M. J. Rane, D. W. Powell, J. B. Klein, and K. R. McLeish, "Differential mitogen-activated protein kinase stimulation by $\mathrm{F} c \gamma$ receptor IIa and Fc $\gamma$ receptor IIIb determines the activation phenotype of human neutrophils," The Journal of Immunology, vol. 164, no. 12, pp. 6530-6537, 2000.

[143] M. Aloulou, S. B. Mkaddem, M. Biarnes-Pelicot et al., "IgG1 and IVIg induce inhibitory ITAM signaling through $\mathrm{Fc}_{\mathrm{c}} \gamma \mathrm{RIII}$ controlling inflammatory responses," Blood, vol. 119, no. 13, pp. 3084-3096, 2012.

[144] B. Walzog, S. Offermanns, A. Zakrzewicz, P. Gaehtgens, and K. Ley, " $\beta 2$ integrins mediate protein tyrosine phosphorylation in human neutrophils," Journal of Leukocyte Biology, vol. 59, no. 5, pp. 747-753, 1996.

[145] M. Petersen, J. D. Williams, and M. B. Hallett, "Cross-linking of $\mathrm{CD} 11 \mathrm{~b}$ or $\mathrm{CD} 18$ signals release of localized $\mathrm{Ca}^{2+}$ from intracellular stores in neutrophils," Immunology, vol. 80, no. 1, pp. 157-159, 1993.

[146] J. NGSIKORSKI, "Calcium signaling capacity of the CD11b/CD18 integrin on human neutrophils 1," Experimental Cell Research, vol. 195, no. 2, pp. 504-508, 1991.

[147] A. T. L. T. Loi, "Dissociation of the Fc $\gamma$ RII/Mac-1 complex on neutrophils changes the functionality of Mac-1 (CD11b/CD18)," in Phenotypes in COPD Visualized by Changes in Neutrophil Activation, p. 39, Dissertation, Netherlands, 2014.

[148] W. van der Meer, P. Pickkers, C. S. Scott, J. G. van der Hoeven, and J. K. Gunnewiek, "Hematological indices, inflammatory markers and neutrophil CD64 expression: comparative trends during experimental human endotoxemia," Journal of Endotoxin Research, vol. 13, no. 2, pp. 94-100, 2016.

[149] M. A. Cassatella, I. Guasparri, M. Ceska, F. Bazzoni, and F. Rossi, "Interferon-gamma inhibits interleukin-8 production by human polymorphonuclear leucocytes," Immunology, vol. 78, no. 2, pp. 177-184, 1993.
[150] H. R. Petty, R. G. Worth, and R. F. Todd, "Interactions of integrins with their partner proteins in leukocyte membranes," Immunologic Research, vol. 25, no. 1, pp. 75-96, 2002.

[151] M. A. Williams and J. S. Solomkin, "Integrin-mediated signaling in human neutrophil functioning," Journal of Leukocyte Biology, vol. 65, no. 6, pp. 725-736, 1999.

[152] R. Ostuni, I. Zanoni, and F. Granucci, "Deciphering the complexity of Toll-like receptor signaling," Cellular and Molecular Life Sciences, vol. 67, no. 24, pp. 4109-4134, 2010.

[153] D. M. Zarewych, A. L. Kindzelskii, R. F. Todd III, and H. R. Petty, "LPS induces CD14 association with complement receptor type 3, which is reversed by neutrophil adhesion," The Journal of Immunology, vol. 156, no. 2, pp. 430-433, 1996.

[154] B. P. Thornton, V. Vetvicka, M. Pitman, R. C. Goldman, and G. D. Ross, "Analysis of the sugar specificity and molecular location of the beta-glucan-binding lectin site of complement receptor type 3 (CD11b/CD18)," The Journal of Immunology, vol. 156, no. 3, pp. 1235-1246, 1996.

[155] S. D. Wright and M. T. Jong, "Adhesion-promoting receptors on human macrophages recognize Escherichia coli by binding to lipopolysaccharide," Journal of Experimental Medicine, vol. 164, no. 6, pp. 1876-1888, 1986.

[156] L. B. Balsam, T. W. Liang, and C. A. Parkos, "Functional mapping of $\mathrm{CD} 11 \mathrm{~b} / \mathrm{CD} 18$ epitopes important in neutrophil-epithelial interactions: a central role of the I domain," The Journal of Immunology, vol. 160, no. 10, pp. 5058-5065, 1998.

[157] T. H. Flo, L. Ryan, L. Kilaas et al., "Involvement of CD14 and $\beta_{2}$-integrins in activating cells with soluble and particulate lipopolysaccharides and mannuronic acid polymers," Infection and Immunity, vol. 68, no. 12, pp. 6770-6776, 2000.

[158] R. Osicka, A. Osickova, S. Hasan, L. Bumba, J. Cerny, and P. Sebo, "Bordetella adenylate cyclase toxin is a unique ligand of the integrin complement receptor 3," eLife, vol. 4, 2015.

[159] S. M. Violette, J. R. Rusche, S. R. Purdy, J. G. Boyd, J. Cos, and S. Silver, "Differences in the binding of blocking anti-CD11b monoclonal antibodies to the A-domain of CD11b," The Journal of Immunology, vol. 155, no. 6, pp. 3092-3101, 1995.

[160] R. R. Ingalls, M. A. Arnaout, and D. T. Golenbock, "Outsidein signaling by lipopolysaccharide through a tailless integrin," The Journal of Immunology, vol. 159, no. 1, pp. 433-438, 1997.

[161] M. H. Faridi, M. M. Altintas, C. Gomez, J. C. Duque, R. I. Vazquez-Padron, and V. Gupta, "Small molecule agonists of integrin CD11b/CD18 do not induce global conformational changes and are significantly better than activating antibodies in reducing vascular injury," Biochimica et Biophysica Acta, vol. 1830, no. 6, pp. 3696-3710, 2013.

[162] C. T. Lefort, Y.-M. Hyun, J. B. Schultz et al., "Outside-in signal transmission by conformational changes in integrin Mac1," The Journal of Immunology, vol. 183, no. 10, pp. 6460 6468, 2009.

[163] J. Stockl, O. Majdic, W. F. Pickl et al., "Granulocyte activation via a binding site near the $\mathrm{C}$-terminal region of complement receptor type $3 \alpha$-chain (CD11b) potentially involved in intramembrane complex formation with glycosylphosphatidylinositol-anchored Fc $\gamma$ RIIIB (CD16) molecules," The Journal of Immunology, vol. 154, no. 10, pp. 5452-5463, 1995. 
[164] J. Loyau, P. Malinge, B. Daubeuf et al., "Maximizing the potency of an anti-TLR4 monoclonal antibody by exploiting proximity to Fc $\gamma$ receptors," MAbs, vol. 6, no. 6, pp. 16211630, 2014.

[165] C. Hellberg, L. Molony, L. Zheng, and T. Andersson, " $\mathrm{Ca}^{2+}$ signalling mechanisms of the $\beta_{2}$ integrin on neutrophils: involvement of phospholipase $\mathrm{C}_{\gamma 2}$ and $\operatorname{Ins}(1,4,5) \mathrm{P}_{3}$," Biochemical Journal, vol. 317, no. 2, pp. 403-409, 1996.

[166] K. F. Wong, J. M. Luk, R. H. Cheng, L. B. Klickstein, and S. T. Fan, "Characterization of two novel LPS-binding sites in leukocyte integrin $\beta$ A domain," Federation of American Societies for Experimental Biology Journal, vol. 21, no. 12, pp. 32313239, 2007.

[167] L. Zhang and E. F. Plow, "Amino acid sequences within the $\alpha$ subunit of integrin $\alpha_{\mathrm{M}} \beta_{2}$ (Mac-1) critical for specific recognition of C3bi," Biochemistry, vol. 38, no. 25, pp. 8064-8071, 1999.

[168] E. A. Medvedev, T. Flo, R. R. Ingals et al., "Involvement of CD14 and complement receptors CR3 and CR4 in nuclear factor-kappaB activation and TNF production induced by lipopolysaccharide and group B streptococcal cell walls," The Journal of Immunology, vol. 160, no. 9, pp. 4535-4542, 1998. 